\title{
Noncompetes in a Downsizing World
}

\author{
CHARLES A. SULLIVAN*
}

\section{TABLE OF CONTENTS}

\begin{tabular}{|c|c|}
\hline \multicolumn{2}{|r|}{ ABSTRACT } \\
\hline I. & 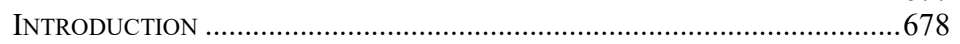 \\
\hline II. & 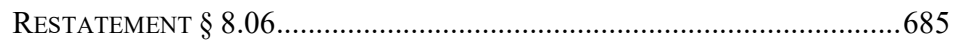 \\
\hline III. & THE COMMON LAW UNDERLYING THE RESTATEMENT.... \\
\hline IV. & 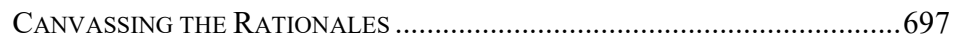 \\
\hline V. & A FRESH LOOK \\
\hline VI. & A No-PROBLEM PROBLEM? \\
\hline VII. & 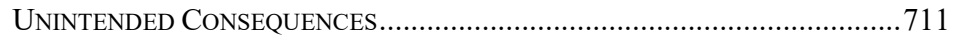 \\
\hline VIII. & 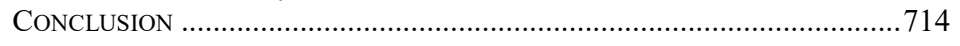 \\
\hline
\end{tabular}

\begin{abstract}
As the nation confronts multiple federal and state attacks on employee noncompetition agreements ("NCAs"), one issue has remained relatively obscure: may an employer that terminates a worker for reasons not related to performance nevertheless enforce an NCA? A scattering of cases mostly holds no, and the recent Restatement of Employment Law's agreement

* $\quad$ (C) 2021 Charles A. Sullivan. Professor of Law, Seton Hall Law School. I thank Rachel Arnow-Richman for sharing some thoughts on this topic. As always, she is insightful, and my ideas more or less align with her thinking on the core issue addressed. In contrast, Steve Willborn was not persuaded by my argument, but he did make several helpful suggestions. And my thanks to colleagues Tim Glynn, who alerted me to gaps in my thinking and Ed Hartnett, who posed some critical questions (critical in both senses of the word!). Thanks also to Professor T. Leigh Anenson for a helpful conversation on equity. Finally, my gratitude to Esad Metjahic, Seton Hall class of 2021, for excellent research assistance and for invaluable help in delivering a Contracts course in a time of COVID.
\end{abstract}


with those decisions is likely to be very influential for the great majority of jurisdictions that have not yet addressed the question but may be forced to in light of massive COVID-related layoffs.

This Article supports the Restatement's proposed rule, while exploring the fascinating doctrinal and policy issues implicated in the question. Ultimately, it sees the rule as rooted in concerns about fairness to employees that are typically given short shrift in current doctrine. This is true even for a Restatement that otherwise seems decided to opt for an economic approach that would validate NCAs that are "reasonably tailored" to defined legitimate employer interests.

Adoption of a rule denying enforcement in such situations also poses some interesting second-order questions, such as how to determine when a termination is performance-related and probable employer responses to a new dispensation. All are explored in the pages that follow.

\section{INTRODUCTION}

One of the little-noticed contributions of the American Law Institute's recent Restatement of Employment Law ${ }^{1}$ was its prescription that postemployment noncompetition agreements ("NCAs") ${ }^{2}$ should be unenforceable when the employee has been terminated without cause. Although case authority leans in this direction, ${ }^{3}$ it can scarcely be described as robust, and the Restatement's endorsement of the principle may prove critical in convincing the courts to generally adopt it. Judicial acceptance

1. Restatement of EMP. L. (Am. L. InSt. 2015). For reasons peculiar to the American Law Institute (ALI), earlier drafts are sometimes referred to as the "Third" Restatement, although this was the Institute's first attempt to restate the law relating to employment and the final version omits the word "Third."

2. "Noncompetition" clauses or postemployment restraints of trade are sometimes distinguished from theoretically lesser restraints such as nonsolicitation clauses, which may be aimed at customers and co-workers. See Orly Lobel, Gentlemen Prefer Bonds: How Employers Fix the Talent Market, 59 SANTA CLARA L. REV. 663, 678 (2020) (describing a variety of vertical restraints imposed by employers on their workers). For present purposes, no distinction will be drawn among the varying provisions unless otherwise noted since the functional reach of any given restraint depends on the context.

3. See infra Section III. 
of such a rule could scarcely be timelier in view of the large-scale layoffs of employees ${ }^{4}$ that accompanied the COVID-19 pandemic. ${ }^{5}$

The Restatement has been frequently criticized as being largely retrograde, both overall ${ }^{6}$ and specifically with respect to its treatment of employee NCAs. ${ }^{7}$ Indeed, those sections are broadly consistent with the rules laid down more than three decades previously in the Restatement (Second) of Contracts. ${ }^{8}$ And that despite indications that the law is already moving on in this area. ${ }^{9}$ The Restatement was finally approved only in 2015, at which point there was already increasing dissatisfaction with the traditional

4. Although the term "employee" is a frequently contested label in applying regulatory regimes, see Samuel R. Bagenstos, Consent, Coercion, and Employment Law, 55 HaRV. C.R.-C.L. L. REv. 409, 443-50 (2020), the common law cases dealing with covenants in restraint of trade seem unconcerned with the "control" or alternative tests that dominate questions of statutory application. Indeed, a less noticed branch of the governing doctrine concerns restraints entered into in connection with the sale of a business, see, e.g., Mitchel v. Reynolds [1711] 24 QB 347 at 347-48 (Eng.), although there are distinctive issues in that context. In any event, the discussion that follows may well apply to "independent contractors" as well as employees. See Ag Spectrum Co. v. Elder, 865 F.3d 1088, 1088-93 (8th Cir. 2017) (invalidating NCA with independent contractor under Iowa law).

5. The pandemic may also be shifting other legal norms regarding noncompetes. See Crystal Woods \& Micala Bernardo, Restrictive Covenants and the Pandemic: An Altered Landscape for Employers, LAB. DisH (June 2, 2021), https://www.labordish.com/ 2021/06/restrictive-covenants-and-the-pandemic-an-altered-landscape-for-employers/\# page $=1$ [https://perma.cc/A9ZX-498U] (reporting a variety of legislative and judicial developments, including heightened scrutiny of NCAs by the courts and a number of pending bills that would further restrict their use).

6. See, e.g., The Labor Law Group Symposium on the Restatement of Employment Law, 21 EMP. RTS. \& EMP. POL'Y J. 245 (2017); Papers from the American Bar FoundationThe Labor Law Group Conference on the Proposed Restatement of Employment Law, 16 EMP. RTS. \& EMP. POL'Y J. 359 (2012); Labor Law Group - U.C. Hastings Symposium on the Proposed Restatement of Employment Law, 13 EMP. RTS. \& EMP. POL'Y J. 1 (2009).

7. See Alan Hyde, A Brief User's Guide to Restatement of Employment Law Chapter 8, Employee Obligations and Restrictive Covenants, 21 EMP. RTS. \& EMP. POL'Y J. 623, 626-28, 630-31, 638-39, 642, 644 (2017); Michael Selmi, Trending and the Restatement of Employment Law's Provisions on Employee Mobility, 100 CORNELL L. REV. 1369, 1375-76, 1379, 1385-88 (2015); Catherine Fisk \& Adam Barry, Contingent Loyalty and Restricted Exit: Commentary on the Restatement of Employment Law, 16 EMP. RTS. \& EMP. POL'Y J. 413, 440, 445 (2012).

8. ReSTATEMENT (SECOND) OF CONTS. $\S \S 187-188$ (AM. L. INST. 1979).

9. Rachel S. Arnow-Richman, The New Enforcement Regime: Revisiting the Law of Employee Competition (and the Scholarship of Professor Charles Sullivan) with 2020 Vision, 50 Seton Hall. L. Rev. 1223, 1224 (2020) ("But times are changing. In the last decade, there has been a surge in public initiatives targeting employers' use and enforcement of restraints against employee competition-what I refer to as the "new enforcement regime."”). 
standards governing enforcement of postemployment restraints of tradedissatisfaction that has only increased in the years since. ${ }^{10}$ Nevertheless, the Restatement has advanced the ball in noncompete law in at least some respects, ${ }^{11}$ and one of its unnoticed innovations is the subject of this Article.

To set the stage for that discussion, it may help to recap recent developments. Contrary to the traditional view that postemployment restraints are efficiency-enhancing, ${ }^{12}$ the meta-critique of influential scholars is that NCAs tend to restrict innovation and entrepreneurship. ${ }^{13}$ That perspective was already gaining academic adherents and attention in state legislatures by the time the Restatement was promulgated, ${ }^{14}$ and particularly obnoxious

10. Id.

11. For example, Professor Hyde praises the Restatement for "increasing the evidentiary and persuasive burden on any plaintiff employer seeking to enforce a noncompete," thus "point[ing] the way to a more rigorous analysis in the states that historically have enforced noncompetes, often on no greater showing than that the employee signed them." Hyde, supra note 7, at 627-28. And, in an earlier article, I recognized that the Restatement tightened the criteria for modifying overly broad covenants to make them reasonable although I criticized it for not going far enough. See Charles A. Sullivan, Restating Employment Remedies, 100 CoRnell L. ReV. 1391, 1397-98 (2015). See infra note 152 .

12. See Stewart E. Sterk, Restraints on Alienation of Human Capital, 79 VA. L. REV. 383, 406-07 (1993). The essence of that argument was that, absent protection from future competition by former employees, employers would operate at less than optimal scale in order not to share trade secrets or customer contacts or would implement expensive workarounds to protect their interests. See Jonathan M. Barnett \& Ted Sichelman, The Case for Noncompetes, 87 U. CHI. L. REV. 953, 967, 969-74 (2020).

13. Sometimes called the "Route 128" argument, the critique centers on the greater success of Silicon Valley as compared to Boston's Route 128; that disparity is attributed in large part to innovation-enhancing "knowledge spillovers" resulting from the high employee mobility enabled by California's prohibition on employment noncompetes. Ronald J. Gilson, The Legal Infrastructure of High Technology Industrial Districts: Silicon Valley, Route 128, and Covenants Not to Compete, 74 N.Y.U. L. REv. 575, 589-603 (1999). Although Professor Gilson's work is more than two decades old, newer scholarship has built on that insight. See, e.g., Orly Lobel, The New Cognitive Property: Human Capital Law and the Reach of Intellectual Property, 93 TEX. L. REV. 789, 853 (2015) ("Restrictions on the flow of knowledge [through noncompetes and other devices] contaminate market flows and diminish both the incentives to move efficiently in the market and the incentives to innovate."); Yifat Aran, Note, Beyond Covenants Not to Compete: Equilibrium in HighTech Startup Labor Markets, 70 STAN. L. ReV. 1235, 1238-40 (2018); ORLY LOBEL, Talent Wants to Be Free: Why We Should Learn to Love LeaKs, Raids, and Free Riding 51 (2013). See also On Amir \& Orly Lobel, Driving Performance: A Growth Theory of Noncompete Law, 16 STAN. TECH. L. REV. 833, 846, 862, 865-66 (2013) (noncompetes may be self-defeating in terms of employer interests by dampening employees' incentives to improve their skills). But see Barnett \& Sichelman, supra note 12, at 953 ("We argue that this zero-enforcement position lacks a sound basis in theory or empirics.").

14. See supra note 12 and accompanying text. 
examples of employer use of NCAs were drawing public scorn, ${ }^{15}$ law enforcement interest, ${ }^{16}$ and legislative action. ${ }^{17}$

Professor Rachel Arnow-Richman has helpfully taxonomized these recent legislative efforts as falling under three headings: "“[1] vulnerable worker bans' that prohibit noncompetes with low-wage, low-skilled workers; [2] 'California-style bans' that seek to void all forms of employee noncompetes; and [3] 'middle way' statutes that impose select procedural requirements and substantive limitations on how, where, and under what conditions noncompetes may be imposed and enforced." 18

The first reform, banning noncompetes for "low-wage" workers, has had the most success to date ${ }^{19}$ although there have been some enactments shielding doctors - scarcely low-wage workers-and other health care workers. ${ }^{20}$

While California-style abolition has not been widely successful, ${ }^{21}$ the District of Columbia recently adopted a law that bars almost all noncompetes, and even goes further than California in barring restrictions on competition during employment. ${ }^{22}$ And recent enactments in at least four other jurisdictions show surprising support for more sweeping reform, and,

15. The poster child for this is Jimmy-John's routine use of NCAs for its sandwich makers. See Neil Irwin, When the Guy Making Your Sandwich Has a Noncompete Clause, N.Y. TimES: UPSHOT (Oct. 14, 2014), https://www.nytimes.com/2014/10/15/upshot/ when-the-guy-making-your-sandwich-has-a-noncompete-clause.html [https://perma.cc/ D68V-7RXW].

16. Arnow-Richman, supra note 9, at 1235

17. See id. at 1231 .

18. Id.

19. Professor Arnow-Richman lists seven states with such enactments; Illinois, Maine, Maryland, Massachusetts, New Hampshire, Rhode Island, and Washington, with bills pending in several others. Id. at 1232 n.37. Since then, Virginia, VA. CoDE ANN. $\S$ 40.1-28.7:8 (2020); Oregon, Or. Rev. Stat. § 653.295 (2021); and Nevada, Nev. Rev. Stat. Ann. § 613.195598A.010 (2021), have joined the list as has the District of Columbia although that ban is far broader. See infra note 22.

20. E.g., CONN. GEN. STAT. § 20-14p (2016). See also IND. CodE § 25-22.5-5.5-2(4) (2020) (requiring noncompete agreements for physicians to, inter alia, provide for a right to buy out the restriction at a "reasonable price").

21. Ellen Rubin, Most States Still Enforce Noncompete Agreements-And It's Stifling Innovation, FORTUNE (June 26, 2019, 11:34 AM), https://fortune.com/2019/06/26/ states-noncompete-agreements-innovation/ [https://perma.cc/PH5T-TTCR].

22. Ban on Non-Compete Agreements Amendment Act of 2020, 2020 D.C. Law 23-209. See New Year, New Rules: The District of Columbia's New Ban on Non-Compete Agreements, https://www.lexology.com/library/detail.aspx?g=243ab964-ff62-4ace-9b8ba489898a2cd3 [https://perma.cc/Z2QB-QZ7X]. 
perhaps even more startling, this includes both red and blue states. ${ }^{23}$ Thus, Oklahoma now bars noncompetes, although it permits nonsolicitation agreements; ${ }^{24}$ Hawaii bars them for the tech sector; ${ }^{25}$ and Idaho, after passing legislation to strengthen such agreements, reversed field in the wake of adverse reaction and repealed that law. ${ }^{26}$ Meanwhile, a multiyear effort to reform Massachusetts law to bring it in line with the California model failed but resulted in reforms that make the state much less hospitable to NCAs. ${ }^{27}$

Massachusetts law and related but less comprehensive enactments in several other states implement reforms such as limiting the length of

23. See Arnow-Richman, supra note 9, at 1236-37.

24. Professor Arnow-Richman reports the Oklahoma story, where the legislature passed amendments, the most recent in 2016, which permit nonsolicitation agreements, while declaring all other forms of restraint "void and unenforceable," making Oklahoma a nonenforcement state. Id. at 1237.

25. HAW. REV. StAT. § 480-4(d) (2020).

26. Idaho enacted a "business friendly" noncompete law in 2016, mostly by rebuttably presuming irreparable harm from breach, only to receive bad national press as making it harder for start-ups in the state. See Nicole Snyder \& A. Dean Bennett, Idaho Legislature Repeals 2016 Changes to Non-Compete Law, EmPS.' L. Blog (Apr. 9, 2018), https:// www.employerslawyersblog.com/2018/04/idaho-legislature-repeals-2016-changes-to-noncompete-law.html [https://perma.cc/53TH-AKHP]. Business leaders signed a letter asking the governor and legislature to repeal the law, which promptly happened in 2018. S. 1287, 64th Leg., 2d Reg. Sess. (Idaho 2018); see Snyder \& Bennett, supra.

27. It is not a coincidence that Massachusetts, the home to Route 128, should have been a battleground between those who would abolish, or at least substantially limit noncompetes, and those who prefer the traditional tests. As the legislative compromise finally emerged, NCAs in that state remain generally permitted but subject to eight requirements:

(1) be in writing, signed, and expressly state the employee has a right to counsel;

(2) if entered into after being hired, provide "fair and reasonable consideration independent from the continuation of employment"; (3) not be broader than necessary to protect an employer's trade secret, confidential information, and goodwill; (4) not last more than one year; (5) provide a reasonable geographic area that does not exceed the area the employee had a material presence in during the last two years of employment; (6) provide a reasonable scope that is limited to types of services provided by the employee during the last two years of employment; (7) provide a "garden leave" clause, which requires the employer to pay fifty-percent of the employee's highest annualized base salary for the restricted period; and (8) "be consonant with public policy."

Kelly Krause, Comment, Turning Wisconn Valley into the Next Silicon Valley: Reforming Wisconsin Non-Compete Law to Attract High-Tech Employers, 103 MARQ. L. REV. 237, 255 n.141 (2019) (referencing what is now MASs. GEN LAWS ch. 149, § 24L(b) (2018)); see also Michael G. Feblowitz, Note, Repaving Route 128: How New Legislation in Massachusetts Impacts the Noncompete Debate, 61 B.C. L. REV. 2263, 2277-78 (2020). 
postemployment restraints ${ }^{28}$ and specifying notice ${ }^{29}$ and other conditions for such agreements ${ }^{30}$ as well as tightening the requirements for a "reasonable" restraint, ${ }^{31}$ and sometimes providing remedies beyond voiding the contract for employer overreaching. ${ }^{32}$ Alone among those states, Massachusetts also requires "garden leave": ${ }^{33}$ payment to a former employee during the restricted period - although arguably that provision may be easily avoided. ${ }^{34}$ And, of particular interest for this paper, Massachusetts bars enforcement of noncompetes for employees laid off without cause. ${ }^{35}$ Beyond these state enactments, there are also efforts for greater regulation at the federal level, ${ }^{36}$ and the Uniform Law Commission has issued a recommended law

28. See ch. 149, § 24L(b)(iv) (limiting non-compete agreements to one year); WASH. REV. CODE. § 49.62.020(2) (2019) (providing a rebuttable presumption of no more than 18 months).

29. Massachusetts requires noncompetes to be in writing, signed by the employee, and to explicitly advise the employee of her right to consult an attorney. See ch. 149, § 24L(b)(i).

30. Massachusetts requires "fair and reasonable consideration" above and beyond continuation of employment if the agreement is not entered into at the outset of employment. See ch. 149, § 24L(b)(ii). Professor Arnow-Richman characterizes these as "mid-term modifications," Arnow-Richman, supra note 9, at 1239 n.69, and reports that both Oregon and Washington require consideration beyond continued employment. See id. at 1239; WASH. ReV. CODE § 49.62.020(1)(a)(ii) (2019); OR. REV. STAT. § 653.295(1)(a)(B) (2020) (requiring such an agreement to be "entered into upon a subsequent bona fide advancement" in the employee's position).

31. Professor Arnow-Richman canvasses these enacted and proposed state reforms more thoroughly. See Arnow-Richman, supra note 9, at 1238-41.

32. Id. at 1241 (citing WASH. REV. CODE ANN. § 49.62 .080 (West 2019) (creating a private right of action)).

33. See generally Charles A. Sullivan, Tending the Garden: Restricting Competition via “Garden Leave," 37 BERKELEY J. EMP. \& LAB. L. 293 (2016).

34. Chapter 149, section 24L(b)(vii) of the Massachusetts General Laws entitles employees required to sit out to be paid $50 \%$ of their base salary during the restricted period, although the statute provides that an agreement providing no such compensation is valid so long as the employee receives "mutually-agreed upon consideration." Ch. 149, $\S 24 \mathrm{~L}(\mathrm{~b})$ (vii). Arguably, whatever compensation the parties agreed to could be considered to incorporate consideration for the relinquishment of garden leave.

35. Id. § $24 \mathrm{~L}$ (c) ("A noncompetition agreement shall not be enforceable against the following types of workers: . . . employees that have been terminated without cause or laid off . ..."). The statute provides no definition of cause.

36. Executive Order on Promoting Competition in the American Economy (July 9, 2021), https://www.whitehouse.gov/briefing-room/presidential-actions/2021/07/09/executiveorder-on-promoting-competition-in-the-american-economy/ [https://perma.cc/VD9A-F7SF] (asking, inter alia, the Federal Trade Commission to consider "curtail[ing] the unfair use of non-compete clauses and other clauses or agreements that may unfairly limit worker mobility"); Petition to the Federal Trade Commission for Rulemaking to Prohibit Worker 
on noncompetes that addresses a variety of issues, including exempting low-income workers. ${ }^{37}$

Largely unnoticed in this debate, however, was a pro-competitive innovation of the Employment Restatement, which declared otherwise reasonable NCAs unenforceable when the employee is terminated without cause. ${ }^{38}$ This has enormous potential benefit for workers-especially in an economy dealing with the disruptions of COVID-19. The number of individuals laid off as a result of the closures is in the tens of millions, ${ }^{39}$ and it seems likely that millions will not regain their jobs when the crisis abates. ${ }^{40}$ Given the pervasiveness of noncompetition agreements in the United States, a substantial percentage of these are undoubtedly subject to noncompetes ${ }^{41}$ although layoffs seem to disproportionately affect lowerpaid workers who are less likely to have signed an NCA to begin with. ${ }^{42}$

Non-Compete Clauses, Open MKTS. InSt. (Mar. 20, 2019), https://www.openmarkets institute.org/publications/petition-3-20-2019 [https://perma.cc/UF6F-6W6B]. See generally Lobel, supra note 2.

37. See Unif. Restrictive Emp. Agreement Act $\S 5$ (Unif. L. Comm’n 2021). Section 5 declares many restrictive employment agreements unenforceable for many lowwage workers. $I d$. It permits them for higher-wage workers when the worker "(A) voluntarily quits without good cause attributable to the employer; (B) is terminated for substantial misconduct or individual performance related cause; or (C) has completed the agreed work or finished the term of the contract." Id.

38. RESTATEMENT OF EMP. L. § $8.06 \mathrm{cmt}$. f(AM. L. INST. 2015).

39. Rachel Arnow-Richman, Temporary Termination: A Layoff Law Blueprint for the COVID Era, 64 WASH. U. J.L. \& POL'Y 1, 2 (2021) ("Between March and July of 2020, over 50 million individuals lost their jobs in the wake of government shut down orders and the cessation of ordinary commercial life.").

40. Jeanna Smialek \& Alan Rappeport, Fed Leaves Rates Unchanged and Projects Years of High Unemployment, N.Y. TIMES (June 10, 2020), https://www.nytimes.com/ 2020/06/10/business/economy/federal-reserve-rates-unemployment.html [https://perma.cc/ YQ3R-UG9X]. In their first economic projections this year, Federal officials indicated that they expect the unemployment rate to end 2020 at 9.3 percent and remain elevated for some time, coming in at 5.5 percent in 2022. Id. That would be well above the level they expect to prevail over the longer run in a healthy economy and far above the historically low jobless rates that preceded the virus. Id.

41. OfF. OF ECON. POL'y, U.S. DeP'T Of THE TREASURy, NON-COMPETE CONTRACTS: ECONOMIC EFFECTS AND POLICY IMPLICATIONS 6 (2016) (estimating that 30 million workers are bound by noncompetes); Evan Starr, JJ Prescott \& Norman Bishara, Noncompete Agreements in the U.S. Labor Force, 64 J.L. \& ECON. 53, 60 (2021); see also Christopher B. Seaman, Noncompetes and Other Post-Employment Restraints on Competition: Empirical Evidence from Trade Secret Litigation, 72 HASTINGS L.J. 1183, 1183 (2021) (providing an empirical study of noncompetes in trade secret litigation showing that NCAs "are more frequently enforced against technical and sales personnel than high-ranking corporate executives [and] ... are common for employees with a base salary below $\$ 100,000$ per year")

42. Winnie Hu, Juliana Kim \& Jo Corona, 'It Makes Me Angry': These Are the Jobless in a City Filled with Wealth, N.Y. TIMES (Dec. 7, 2020), https://www.nytimes.com/2020/ 12/07/nyregion/bronx-unemployment-covid.html? searchResultPosition=3 [https:// 
It is also true that most former employers, assuming they survive, may not seek to enforce these NCAs. But not only may the mere existence of the NCA tend to suppress competition, ${ }^{43}$ but some employers will seek to enforce such agreements, which will raise the question whether an employee laid off by her employer remains subject to any noncompete she signed.

According to the Restatement, the answer should be no: if the employee either quits voluntarily or is fired for "cause," an otherwise reasonable NCA is enforceable. ${ }^{44}$ In contrast, an NCA is not enforceable against an employee laid off in a corporate downsizing. ${ }^{45}$ However, as we will see, the drafters were more than a little cagey in framing the rule, and its vague phrasing may limit its impact. ${ }^{46}$ Further, the case authority on which the Restatement rule is based is not robust. Nevertheless, refusing to enforce noncompetes in these circumstances seems to be the correct approach for the courts and should be added to the various legislative reforms now percolating.

\section{RESTATEMENT $\S 8.06$}

Consistent with the law in most states, $\S 8.06$ of the Restatement of Employment Law generally approves restrictive covenants "reasonably tailored" to specified legitimate employer interests. ${ }^{47}$ However, it carves out exceptions for instances in which "(a) the employer discharges the employee on a basis that makes enforcement of the covenant inequitable, [and] (b) the employer acted in bad faith in requiring or invoking the covenant." 48 Since there is a separate exception for material breach by the

perma.cc/BAG3-Y25M] ("Pandemic job losses have disproportionately hurt low-paid service workers [in New York] who tend to be poor and people of color.").

43. See infra note 152 .

44. RestATEMENT OF EMP. L. $§ 8.06$ cmt. f (AM. L. Inst. 2015).

45. Id.

46. There may also be situations in which the doctrines of impracticability or frustration of purpose might be invoked to challenge an NCA, but that question is beyond the scope of this Article. See Restatement (SECOnd) of Conts. ch. 11, § 266 (Am. L. INST. 1981)

47. The Restatement defines employer protected interests in $\$ 8.07(\mathrm{~b})$ : “(1) trade secrets, as defined in $\S 8.02$, and other protectable confidential information that does not meet the definition of trade secret; (2) customer relationships; (3) investment in the employee's reputation in the market; or (4) purchase of a business owned by the employee." RESTATEMENT OF EMP. L. \$ 8.07(b) (AM. L. INST. 2015).

48. Section 8.06 provides in full:

Except as otherwise provided by other law or applicable professional rules, a covenant in an agreement between an employer and a former employee restricting 
employer, ${ }^{49}$ these paragraphs envision some other basis making court enforcement inappropriate, ${ }^{50}$ but the vague phrasing renders the meaning of these terms unclear.

That's in part because the two provisions each employ protean terms"inequitable" and "bad faith"- but also because it is not clear whether they address two different situations. ${ }^{51}$ Paragraph (a) is aimed at scenarios ex post the NCA while paragraph (b)'s use of the word "requiring" suggests an ex ante focus on the moment the contract was made. But (b)'s use of "invoking" may indicate that even a covenant obtained in good faith may be unenforceable if asserted in bad faith. Thus, both "bad faith" and "inequitable" can come into play in determining whether to enforce a covenant.

Whatever the deficiencies of the blackletter, the Restatement's comments establish that the language is designed to bar enforcement of a restraint if

the former employee's working activities is enforceable only if it is reasonably tailored in scope, geography, and time to further a protectable interest of the employer, as defined in $\S 8.07$, unless:

(a) the employer discharges the employee on a basis that makes enforcement of the covenant inequitable;

(b) the employer acted in bad faith in requiring or invoking the covenant;

(c) the employer materially breached the underlying employment agreement; or

(d) in the geographic region covered by the restriction, a great public need for the special skills and services of the former employee outweighs any legitimate interest of the employer in enforcing the covenant.

RESTATEMENT OF EMP. L. § 8.06 (AM. L. INST. 2015).

Interpreting and enforcing geographic restrictions in NCAs is likely to become more complicated after the pandemic as remote work becomes more common. See Woods \& Bernardo, supra note 5 ("[R] emote work situations involving geographic-based non-compete agreements is [sic] likely to be an area of fertile ground for legal challenges to restrictive covenants in 2021.").

49. ReStatement OF EMP. L. § 8.06 (Am. L. InSt. 2015).

50. Unlike most other employment law issues, the effect of arbitration agreements on this question need not long detain us. While employment contracts usually provide for individual arbitration of disputes, the typical clause carves out the ability of the employer to seek injunctive relief for violation of an NCA, and postemployment restraints of trade continue to be enforced (or not) mainly in court. See Timothy P. Glynn, Interjurisdictional Competition in Enforcing Noncompetition Agreements: Regulatory Risk Management and the Race to the Bottom, 65 WASH. \& LEE L. REV. 1381, 1421 (2008) ("Although an arbitrator may be empowered to award injunction relief, arbitration is typically not conducive to facilitating speedy resolution or providing interim remedies" and employers often desire to join the new employer, who will not be bound by the agreement.); $c f$. Archer \& White Sales, Inc. v. Henry Schein, Inc., 935 F.3d 274, 274-75 (5th Cir. 2019), cert. denied, $141 \mathrm{~S}$. Ct. 656 (2021) (noting that given the carve-out for injunctive relief, there was no unmistakable delegation of the question of arbitrability to the arbitrator).

51. That is not to say that some courts might not invoke "bad faith" when dealing with enforcement in the termination context. See Restatement OF EMP. L. § 8.06(b) (Am. L. INST. 2015). 
the employer terminates the employee without cause even though, for an at-will worker, such action would not be a breach by the employer. ${ }^{52}$ In other words, such an employer does not need cause to terminate but does need cause to enforce an NCA when the employee does not leave voluntarily.

Comment $f$, dealing with terminated employees, provides that "restrictive covenants are generally enforceable against employees who have been discharged for cause" 53 but such "covenants are generally unenforceable against employees who are terminated without cause or who quit employment for cause attributable to the employer. "54

This latter phrasing is reminiscent of concepts used for purposes of unemployment insurance, which bar eligibility on a variety of bases, including quitting without good cause, variously defined..$^{55}$ Comment $f$, however, makes clear that "cause" in this context is performance based. ${ }^{56}$

52. Discharge without cause of an employee working on a definite term contract would bar enforcement under $\S 8.05$ (c)'s exception for employer material breach. See RESTATEMENT OF EMP. L. § 8.06(c) (AM. L. INST. 2015).

53. Id. $\$ 8.06 \mathrm{cmt}$. f.

54. Id. (emphasis added).

55. See, e.g., ConN. Gen. Stat. § 31-236(a) (2020) ("An individual shall be ineligible for benefits: ... (2)(A) If . . the individual has left suitable work voluntarily and without good cause attributable to the employer ...."). "The unemployment compensation system is often characterized as one designed to provide benefits to workers who are 'unemployed through no fault of their own." Deborah Maranville, Workplace Mythologies and Unemployment Insurance: Exit, Voice and Exhausting All Reasonable Alternatives to Quitting, 31 HofsTRA L. REV. 459, 485 (2002). To that end, an employee discharged for "willful misconduct" has no right to benefits, while an employee laid off for economic reasons does. Somewhere in the middle are employees who quit for any number of reasons, some of which might be described as fault attributable to the employer. See, e.g., MinN. STAT. § 268.095(3)(a) (2019) (“(a) A good reason caused by the employer for quitting is a reason: (1) that is directly related to the employment and for which the employer is responsible; (2) that is adverse to the worker; and (3) that would compel an average, reasonable worker to quit and become unemployed rather than remaining in the employment."). See generally Maranville, supra. Other statutes focus less on "cause" than "misconduct" as rendering a former employee ineligible. See, e.g., S.D. CodifIED Laws $\S 61-6-14.1$ (2021) ("As used in this chapter, misconduct is: (1) Failure to obey orders, rules, or instructions, or failure to discharge the duties for which an individual was employed; or (2) Substantial disregard of the employer's interests or of the employee's duties and obligations to the employer; or (3) Conduct evincing such willful or wanton disregard of an employer's interests as is found in deliberate violations or disregard of standards of behavior which the employer has the right to expect of an employee; or (4) Carelessness or negligence of such degree or recurrence as to manifest equal culpability or wrongful intent.").

56. ReSTATEMENT OF EMP. L. $§ 8.06 \mathrm{cmt}$. f. 
It does so by cross-referring to Restatement $\S 2.04(a)$, which addresses when an employer may escape a definite term contract:

An employer has cause for early termination of an agreement for a definite term of employment if the employee has materially breached the agreement, including by persistent neglect of duties; by engaging in misconduct or other malfeasance, including gross negligence; or by being unable to perform the duties of the position due to a long-term disability. 57

This rigorous definition, which excludes terminations in the context of layoffs or downsizing, can be contrasted with paragraph (b) of $\S 2.04$, which has a looser definition of cause for contracts without a definite term and includes a "significant change in the employer's economic circumstances [such] that the employer no longer has a business need for the employee's services." ${ }^{58}$ The pointed failure of $\S 8.06$ to cross-reference $\S 2.04(\mathrm{~b})$ makes clear that the Restatement would not permit enforcement of a covenant against an employee terminated in a reduction in force, no matter how legitimate. Rather, the employee must resign voluntarily ${ }^{59}$ or be fired for her own material breach in order to continue to be subject to a reasonably tailored NCA. ${ }^{60}$

Left largely unaddressed is the middle ground where an employer modifies the terms and conditions of employment (something it is normally permitted to do for at-will workers) leading the employee to quit. Were the employer to have acted to induce the resignation, we might speak in terms of constructive discharge. Indeed, comment $f$ describes "cause attributable to the employer" as "a form of "constructive discharge"" but does not address whether the employer has to intend the employee to leave for that concept to apply. ${ }^{61}$

57. Id. $\S 2.04(\mathrm{a})$.

58. Id. $\S 2.04(\mathrm{~b})$.

59. By its reference to "constructive discharge," comment $f$ makes clear that some resignations may be viewed as involuntary for the purpose of this rule. But that notion is problematic in this context. See discussion infra Section VII.

60. In the $\S 8.06$ (a) context, this is a somewhat odd use of the concept of "material breach" because the usual consequence of so labeling a breach is to relieve the injured party of its reciprocal obligation. See Restatement (SECOND) OF CONTS. § $237 \mathrm{cmt}$. a (AM. L. INST. 1981). In the at-will setting, the employer has no reciprocal obligation to continue employment and the employee can be discharged for any breach or no breach. See also Prop. Tax Representatives, Inc. v. Chatam, 891 S.W.2d 153, 156-57 (Mo. Ct. App. 1995) (exploring the meaning of cause in the NCA context and apparently viewing cause as limited to employee breach of the contract of employment). Section 204(a) also includes as "cause" a no-fault discharge when the employee is disabled and so unable to perform her duties. See RESTATEMENT OF EMP. L. § 204(a). Such employee nonperformance is typically viewed not as a breach but as excused, which would in turn excuse any employer reciprocal obligation. See ReSTATEMENT (SECOND) OF CONTS. § 262 (AM. L. InST. 1981). Such situations will rarely if ever be implicated in connection with enforcing an NCA.

61. Illustration 15 deals with constructive discharge by positing that the NCA is unenforceable when the employee is demoted and deprived of all his staff assistance but 
As for the justification for the rule, the comment is terse. It explains: "An opposite rule would have the perverse consequence of enabling an employer to terminate rather than retain an employee who is performing satisfactorily and then restrict the discharged employee's ability to secure new employment." ${ }^{62}$ This is less an explanation than a repetition of the view that the result would be unfair. The following sentence states: "By the same token, an employer should not be able to obtain enforcement of a restrictive covenant when the employer acts in bad faith, such as by securing the employee's execution of the covenant after planning to discharge the employee." ${ }^{63}$ That is a compelling example of bad faith ${ }^{64}$ but casts no light on other instances of bad faith in "requiring" an NCA much less in "invoking" one.

Several illustrations follow, but Illustration 13 presents the case of the employee discharged for cause, ${ }^{65}$ and 14 and 15 are unenlightening, especially because they not only involve nonenforcement of a noncompete but also forfeiture of apparently earned benefits. ${ }^{66}$ Neither explains either blackletter

does not explicitly deal with the employer's intent to trigger a resignation. RESTATEMENT OF EMP. L. § $8.06 \mathrm{cmt}$. f, illus. 15 (AM. L. INST. 2015). However, the cross reference to comment $\mathrm{c}$ of section 5.01, dealing with the public policy tort, may suggest that there must be at least an intent beyond a normal reorganization to increase efficiency. See discussion infra Section VII.

62. ReSTATEMENT OF EMP. L. $§ 8.06$ cmt. f(AM. L. INST. 2015).

63. Id.

64. Normal contract analysis would seem to also permit the employee to rescind the NCA for misrepresentation in this scenario. Restatement (Second) of Contracts, section 161, provides that:

A person's non-disclosure of a fact known to him is equivalent to an assertion that the fact does not exist in the following cases only: ...

(b) where he knows that disclosure of the fact would correct a mistake of the other party as to a basic assumption on which that party is making the contract and if non-disclosure of the fact amounts to a failure to act in good faith and in accordance with reasonable standards of fair dealing.

RESTATEMENT (SECOND) OF CONTS. $\$ 161$ (AM. L. INST. 1981).

65. See ReStATEMENT OF EMP. L. $\$ 8.06$ cmt. f, illus. 13 (AM. L. InSt. 2015).

66. The Illustrations are:

14. X's employee E, who has access to X's trade secrets, signs a reasonable restrictive covenant as part of an employment agreement with X. The covenant states that $\mathrm{E}$ will forfeit special severance benefits if $\mathrm{E}$ competes with $\mathrm{X}$ within one year of leaving X's employ. X fires $\mathrm{E}$ without cause, and $\mathrm{E}$ then begins working for a competitor. $\mathrm{X}$ may not enforce the covenant against $\mathrm{E}$.

15. Same facts as Illustration 14, except that E quits because $X$, without cause, has constructively discharged (see $\S 5.01$, Comment c) E by demoting E and depriving 
provision although both suggest that enforcement is never appropriate when a discharge is not for cause. ${ }^{67}$

In sum, the Restatement, despite the cryptic phrasing of the blackletter, would bar an employer from enforcing an agreement not to compete, no matter how "reasonable," unless the former employee voluntarily quit or was terminated for her own material breach. ${ }^{68}$ Given the fallout from the COVID crisis, general recognition of such a principle might invalidate thousands of otherwise-enforceable noncompetes.

But a Restatement is, of course, not "law," ${ }^{99}$ and even reading the Restatement to adopt such a conclusion is not enough to assure the unenforceability of noncompetes in this situation. That depends on what the courts will do.

\section{THE COMMON LAW UNDERLYING THE RESTATEMENT}

The case authority regarding the effect of a termination without cause on the enforceability of a NCA is both fragmentary and undertheorized..$^{70}$ Although Restatements may adopt the "better rule," whether or not it is the "majority rule," "71 the Reporters' Notes seem to clearly view some version

him of all customary staff assistance. Because E quit for cause attributable to the employer, $\mathrm{X}$ may not enforce the covenant against $\mathrm{E}$.

See id. $\S 8.06 \mathrm{cmt}$. f, illus. 14, 15. The Reporters' Notes state that Illustrations 14 and 15 are based on Post v. Merrill Lynch, Pierce, Fenner \& Smith, Inc., 397 N.E.2d 358, 360 (N.Y. 1979), which is an atypical example since it involved not only an NCA but the forfeiture of otherwise-earned benefits. Further, the decision was influenced by a "powerfully articulated congressional policy" in ERISA against forfeiture of such benefits. See id. $\S 8.06$ reporters' note to comment f (quoting Post, 397 N.E.2d at 360).

67. See id. $\$ 8.06 \mathrm{cmt}$. f, illus. 14, 15 .

68. See supra note 60.

69. The ALI cautions against interpreting Restatements as one would a statute. See Am. L. Inst., CAPTURING THE VoICE OF THE AMERICAN LAW InSTITUTE: A HANDBOOK FOR ALI REPORTERS AND THOSE WHO REVIEW THEIR WORK 5 (2005) (“Although Restatements are expected to aspire toward the precision of statutory language, they are also intended to reflect the flexibility and capacity for development and growth of the common law. They are therefore phrased not in the mandatory terms of a statute but in the descriptive terms of a judge announcing the law to be applied in a given case.").

70. See Kenneth J. Vanko, "You're Fired! And Don't Forget Your Non-Compete. . ”: The Enforceability of Restrictive Covenants in Involuntary Discharge Cases, 1 DEPAUL Bus. \& CoM. L.J. 1, 2 (2002) ("[C]ourts have not established any clear rules to provide judges, lawyers and parties with guidance in termination cases. The law in this area is relatively undeveloped, perhaps because so few termination cases have made their way through the reported decisions or the courts have not given them much reasoned analysis.").

71. That does not mean that a given Restatement simply puts forth what the Institute determines to be the majority rule. The ALI explains:

A Restatement thus assumes the perspective of a common-law court, attentive to and respectful of precedent, but not bound by precedent that is inappropriate or inconsistent with the law as a whole. Faced with such precedent, an Institute 
of its formulation as adopted by "most courts," or at least most courts that have addressed the issue. ${ }^{72}$ Here is their entire textual summary of the relevant case law: ${ }^{73}$

The case law specifically addressing the enforceability of reasonable restrictive covenants against discharged employees is quite variable. Relatively few jurisdictions have squarely ruled that such covenants are enforceable regardless of the circumstances surrounding the termination of employment. Courts generally consider the circumstances surrounding the employee's termination to be an important, if not decisive, factor in determining whether the restrictive covenant should be enforced. Most courts will not enforce an otherwise reasonable restrictive covenant against an employee who is discharged without cause, who quits for cause attributable to the employer (a form of "constructive discharge"), or who is let go because of a downturn in business. In addition, a number of courts have expressly distinguished the enforceability of restrictive covenants when the employee was fired for cause from the enforceability of restrictive covenants against an employee discharged without cause. 74

Reporter is not compelled to adhere to what Herbert Wechsler called "a preponderating balance of authority" but is instead expected to propose the better rule and provide the rationale for choosing it. A significant contribution of the Restatements has also been anticipation of the direction in which the law is tending and expression of that development in a manner consistent with previously established principles.

AM. L. INST., supra note 69.

72. The Notes function as a kind of legislative history albeit one with the usual problems of resorting to such authority to interpret the blackletter. This is compounded by the fact that, unlike the blackletter and the comments, the Notes are not "official" ALI documents. See id. at 45 ("Unlike the Introduction, Introductory Notes, black letter, and Comment (including Illustrations), the Reporter's (or Reporters') Notes are regarded as the work of the Reporter (or Reporters).").

73. See also Restatement OF EMP. L. $§ 8.06$ reporters' note to comment f ("Many courts have refused, or stated in dicta that they would refuse, to enforce a restrictive covenant against a discharged employee when the employer has acted in bad faith.").

74. Id. (emphasis added) (citations omitted). The Notes also state that New York may or may not adhere to an "employee choice doctrine," which the Restatement rejects. $I d$. Under that rule "the court will enforce a restrictive covenant without regard to its reasonableness if the employer can demonstrate it would have allowed the employee to continue working and receive the benefits of the employment contract but the employee nevertheless quit to work for a competitor." Id. The doctrine is apparently limited to foreclosing receipt of an equity stake or other postemployment benefits. See Devivo Assocs., Inc., v. Nationwide Mut. Ins. Co., 797 F. App'x 661, 663 (2d Cir. 2020) (“Under New York law, courts will enforce a contract provision that conditions receipt of postemployment benefits upon compliance with a restrictive covenant without regard to reasonableness unless the employee was terminated involuntarily and without cause." (citing Morris v. Schroder Cap. Mgmt. Int'1, 859 N.E.2d 503, 507 (N.Y. 2006))). 
Although the Notes recognize a minority position, it is not a strong one because only one of the five cases cited for enforcing covenants without regard to the reason for termination in fact focused on the issue, and that case's result was arguably dictated by a statute. ${ }^{75}$

But neither is the line of authority represented by "most courts" very robust. The italicized sentence is supported by ten cases from nine jurisdictions. ${ }^{76}$ However: the relevant passage in two cases is described as

75. The strongest holding is Twenty Four Collection v. Keller, 389 So. 2d 1062, 1062-63 (Fla. Dist. Ct. App. 1980) (enforcing a noncompetition covenant triggered by a "termination, voluntarily or involuntarily" and declaring that "[t]he only authority the court possesses over the terms of a non-competitive agreement is to determine, as the statute provides, the reasonableness of its time and area limitations"). However, as the quoted language indicates, this decision was rendered under a Florida statute that the court viewed as dictating its result. See id. at 1063.

The other citations, introduced by a "cf." signal, are either inapposite, Weber v. Tillman, 913 P.2d 84, 91-93 (Kan. 1996) (finding that the employee voluntarily left), or involve decisions that ignore the fact that the defendant was terminated without cause. See Ins. Assocs. Corp. v. Hansen, 723 P.2d 190, 190-91 (Idaho Ct. App. 1986); Cellular One, Inc. v. Boyd, 653 So. 2d 30, 31-34 (La. Ct. App. 1995); Hogan v. Bergen Brunswig Corp., 378 A.2d 1164, 1166-67 (N.J. Super. Ct. App. Div. 1977).

Not cited by the Reporters but another decision where the court simply ignored the reason for discharge is James Roberson \& Penhall Co., Inc. v. C.P. Allen Const. Co., Inc., 50 So. 3d 471, 473-74 (Ala. Civ. App. 2010).

76. Bailey v. King, 398 S.W.2d 906, 908 (Ark. 1966) (explaining that a firing "without reasonable cause" might bar enforcement but finding "valid reasons" for ending the employment); Bishop v. Lakeland Animal Hosp., P.C., 644 N.E.2d 33, 36 (Ill. App. Ct. 1994) ("[T] he implied promise of good faith inherent in every contract precludes the enforcement of a non-competition clause when the employee is dismissed without cause.”); Ma \& Pa, Inc. v. Kelly, 342 N.W.2d 500, 502 (Iowa 1984) (recognizing that discharge is a factor cutting against an injunction) (citing Holloway v. Brown, 155 S.E. 917 (Ga. 1930)); Orion Broad., Inc. v. Forsythe, 477 F. Supp. 198, 201 (W.D. Ky. 1979) (distinguishing between an employee who voluntarily resigns and one who is involuntarily terminated; holding an employee to an NCA that deprives her of her livelihood at the "whim" of her employer is "an example of industrial peonage which has no place in today's society"); Macintosh v. Brunswick Corp., 215 A.2d 222, 225-26 (Md. 1965) (holding that restrictive covenant imposed "undue hardship" on employee in part because employee was fired "through no fault of his own"); Post v. Merrill Lynch, Pierce, Fenner \& Smith, Inc., 397 N.E.2d 358, 360-61 (N.Y. 1979) (refusing to enforce a provision requiring forfeiture of retirement benefits for completion when the employee was terminated without cause, in part because of the policy reflected in ERISA); Insulation Corp. of Am. v. Brobston, 667 A.2d 729, 735 (Pa. Super. Ct. 1995) ("The employer who fires an employee for failing to perform in a manner that promotes the employer's business interests deems the employee worthless ... . [Thus, the need to protect itself from the former employee is diminished by the fact that the employee's worth to the corporation is presumably insignificant. Under such circumstances, we conclude that it is unreasonable as a matter of law to permit the employer to retain unfettered control over that which it has effectively discarded as worthless to its legitimate business interests."); Cent. Adjustment Bureau, Inc. v. Ingram, 678 S.W.2d 28, 35 (Tenn. 1984) (explaining that the circumstances of an employee's departure are a factor affecting the reasonableness analysis); Sec. Servs., Inc. v. Priest, 507 S.W.2d 592, 595 (Tex. Civ. App. 1974) (refusing to enforce a restrictive 
"dicta"; 77 other decisions speak in terms of the reason for termination being a "factor" in the reasonableness analysis rather than a free-standing rule; ${ }^{78}$ and some tie it to the clean hands doctrine in equity, perhaps suggesting it may not be relevant in a legal action for damages. ${ }^{79}$ Further, most of the cases are older and some are from lower-level courts. ${ }^{80}$ And not all of them consider a restraint that, by its terms, applies regardless of the reason for termination, and so are arguably distinguishable when such language is present. ${ }^{81}$ Thus, the "most courts" rule is not impressive from a judicial nose-counting perspective, although several cases not cited by the Reporters also provide some support for the rule. ${ }^{82}$

covenant when the employer discharged the employee without cause after obtaining the employee's former customers for itself).

The Notes also cite In re UFG Int'l, Inc., 225 B.R. 51, 56 (Bankr. S.D.N.Y. 1998), which speaks of not enforcing the covenant when the employer "hobble[s] his employee by terminating him without cause." Nevertheless, the employer in that case appeared to be in material breach of the agreement by the termination, which would fall within the $\S 8.06(\mathrm{c})$ exception to enforcement. Id.

77. See Bailey v. King, 398 S.W.2d 906, 908 (Ark. 1966); Ingram, 678 S.W.2d at 35.

78. $M a \& P a$, Inc., 342 N.W.2d at 502; Brobston, 667 A.2d at 735; Ingram, 678 S.W.2d at 35 (explaining that the circumstances of an employee's departure is a factor affecting the reasonableness analysis); see also Frierson v. Sheppard Bldg. Supply Co., 154 So. 2d 151, 155 (Miss. 1963) ("Had the chancellor found that appellant's discharge was arbitrary, capricious, or in bad faith, he could have refused to lend the aid of equity in enforcing the contract."); Cent. Monitoring Serv., Inc. v. Zakinski, 553 N.W.2d 513, 521 (S.D. 1996) (applying balancing test when employee was terminated without cause).

79. Ingram, 678 S.W.2d at 35 ("[A] discharge which is arbitrary, capricious or in bad faith clearly has a bearing on whether a court of equity should enforce a noncompetition covenant." (citing Frierson, 154 So. 2d at 155)); see also Chi. Towel Co. v. Reynolds, 152 S.E. 200, 201 (W. Va. 1930) (denying an injunction on the basis of the "unclean hands" doctrine; the employee had been discharged without notice on the ground that his salary was too high).

80. See e.g., Priest, 507 S.W.2d at 595; Reynolds, 152 S.E. at 201.

81. See, e.g., Bishop, 644 N.E.2d at 36 (refusing to enforce a noncompetition agreement against an employee fired without cause although the employment contract authorized termination by either party "with or without cause"); $M a \& P a, I n c ., 342$ N.W.2d at 502; Rao v. Rao, 718 F.2d 219, 222 (7th Cir. 1983). In contrast, Twenty Four Collection v. Keller, 389 So. 2d 1062, 1063 (Fla. Dist. Ct. App. 1980), looked to precisely such language in finding a clause enforceable despite a no-cause discharge.

82. See Wrigg v. Junkermier, Clark, Campanella, Stevens, P.C., 265 P.3d 646, 653 (Mont. 2011) ("[A]n employer normally lacks a legitimate business interest in a covenant when it chooses to end the employment relationship. Maintenance of the employment relationship represents an employer's best method to prevent competition from an employee.") (citing Rao, 718 F.2d at 224); Econ. Grocery Stores Corp. v. McMenamy, 195 N.E. 747, 748 (Mass. 1935) ("A petition [for an injunction] will not be granted if the conduct of the 
The Reporters cite a separate line of cases in support of paragraph (b): "Many courts have refused, or stated in dicta that they would refuse, to enforce a restrictive covenant against a discharged employee when the employer has acted in bad faith." ${ }^{83}$ These cases can be sorted into several categories, but few are very helpful as to when enforcement is in bad faith. Thus, several refuse to enforce an agreement when the employer is itself in material breach, ${ }^{84}$ which is the province of $\S 8.06(\mathrm{c})$ and a standard contract law principle. ${ }^{85}$ Others enforce a covenant but have dicta suggesting a different result if bad faith were present without indicating what bad faith would consist of in this context. ${ }^{86}$

More helpful are four cases, most in dicta, recognizing that enforcement would be inequitable if the employer extracts an NCA while already planning to terminate the employee and thus eliminate her competition. ${ }^{87}$

plaintiff is savored with injustice touching the transaction, even though there is no sufficient ground for the rescission of the contract."); see also Frierson, 154 So. 2 d at 155 (finding just cause for discharge but noting that "[h]ad the chancellor found that appellant's discharge was arbitrary, capricious, or in bad faith, he could have refused to lend the aid of equity in enforcing the contract.").

Rao could also be cited for this proposition but is viewed by the Reporters as more of a bad faith decision since the termination was claimed to be effected to prevent vesting of an ownership interest in the medical practice, a classic example of violating the implied duty of good faith and fair dealing. Rao, 718 F.2d at 222-24.

83. Restatement Of EMP. L. $§ 8.06$ reporters' note to comment f (AM. L. Inst. 2015).

84. Colonial Life \& Accident Ins. Co. v. Sisco, No. CA 98-751, 1999 WL 328903, at *6-7 (Ark. Ct. App. May 19, 1999); C.G. Caster Co. v. Regan, 410 N.E.2d 422, 426-27 (Ill. App. Ct. 1980); Francorp, Inc. v. Siebert, 126 F. Supp. 2d 543, 547 (N.D. Ill. 2000); Dunning v. Chem. Waste Mgmt., Inc., No. 91 C 2502, 1997 WL 222891, at *11 (N.D. Ill. Apr. 24, 1997).

85. A standard remedy for material breach is the power of the injured party to declare the breached contract at an end. See Restatement (SECOND) OF CONTS. $§ 237$ (AM. L. INST. 1981) (stating that an uncured material breach permits suspension of injured party's duty of performance); see also id. $\S 242$ (noting that "total" breach discharges that duty).

86. Rsch. \& Trading Corp. v. Pfuhl, No. 12527, 1992 WL 345465, at*11-13 (Del. Ch. Nov. 18, 1992); Gomez v. Chua Med. Corp., 510 N.E.2d 191, 195 (Ind. Ct. App. 1987); Cent. Adjustment Bureau, Inc. v. Ingram, 678 S.W.2d 28, 35 (Tenn. 1984).

87. See Robinson v. Comput. Servicenters, Inc., 346 So. 2d 940, 943 (Ala. 1977) (refusing to enforce a restrictive covenant when, at the time the covenant was executed, the employer planned to soon discharge the employee); Kupscznk v. Blasters, Inc., 647 So. 2d 888, 891 (Fla. Dist. Ct. App. 1994) (explaining that hiring and "after a very short time" terminating an at-will worker without cause "might be deemed unconscionable and a court of equity would not permit its perpetuation by entry of an injunction"); Allen v. Rose Park Pharmacy, 237 P.2d 823, 825-26 (Utah 1951) (enforcing restrictive covenant when termination was without cause but suggesting an exception for covenants imposed "wwith intent on the part of the employer that the employment would be only long enough to bind the employee to the covenant, and with a view only of preventing him from working elsewhere"” (quoting Wark v. Ervin Press Corp., 48 F.2d 152, 156 (7th Cir. 1931))); 
A concrete example but surely a rare one. ${ }^{88}$ Another case involves a noncompetition clause sprung on the employee after he had been induced to quit his previous employment; ${ }^{89}$ however, given the pervasiveness of noncompetes today, few current employees could make a plausible claim of surprise. Three of the cited cases involve claims that the employer was motivated to deprive the employee of an otherwise-earned benefit; 90 that's a standard application of the duty but rarely applicable in the NCA setting. ${ }^{91}$ Two others are hard to classify. ${ }^{92}$

Hopper v. All Pet Animal Clinic, Inc., 861 P.2d 531, 541 (Wyo. 1993) (explaining that "if an employer hired an employee at will, obtained a covenant not to compete, and then terminated the employee, without cause, to arbitrarily restrict competition,... such conduct would constitute bad faith.”). See also Edin v. Jostens, Inc., 343 N.W.2d 691, 694 (Minn. Ct. App. 1984) (enforcement inequitable when "management induced [the defendant] into allowing his current contract to expire without signing the new contract, then terminated him for failing to timely sign the new contract"); Crowell v. Woodruff, 245 S.W.2d 447, 450 (Ky. 1951) ("The inequity of the plaintiff's plea for specific performance lies in the fact that having exacted the harsh covenant, he discharged his employee within a brief time.").

88. Not explicitly addressed in the cases is the possibility that the employer's staffing reflects a sincere hope to succeed with its business plan but whose use of NCAs essentially buys an insurance policy against competition should it be less successful and be compelled to cut its workforce.

89. Am. Credit Bureau, Inc. v. Carter, 462 P.2d 838, 841 (Ariz. Ct. App. 1969) (finding no abuse of discretion in denying an injunction when "plaintiff had unclean hands in the formation of this contract" because "plaintiff admits to having successfully induced defendant to leave his previous job and to having him sign the subject agreement on his first day's work").

90. Rao v. Rao, 718 F.2d 219, 222-24 (7th Cir. 1983) (when employer terminated defendant to prevent his exercising his rights under a stock-option plan, that bad faith will bar enforcement of an NCA). The Notes also cite Kroeger v. Stop \& Shop Cos., 432 N.E.2d 566, 572-74 (Mass. App. Ct. 1982), but, although the court there found the forfeiture of retirement benefits inequitable, there seems to be no suggestion of bad faith by plaintiff.

91. The Restatement of Employment Law section 2.07(c) states that:

In any employment relationship, including at-will employment, the employer's implied duty of good faith and fair dealing includes the duty not to terminate or seek to terminate the employment relationship for the purpose of:

(1) preventing the vesting or accrual of an employee right or benefit ....

Restatement of EmP. L. § 2.07(c) (Am. L. Inst. 2015). See infra note 142.

92. In Empiregas, Inc. of Kosciusko v. Bain, 599 So. 2d 971, 975-76 (Miss. 1992), the court found a breach of the duty of good faith in withholding commissions and refused to enforce the noncompete for a variety of reasons, including, apparently, the unfairness of the discharge when the employee had acted in his employer's best interest. Empiregas, Inc. of Kosciusko v. Bain, 599 So. 2d 971, 975-76 (Miss. 1992). See Lantech.com, LLC v. Yarbrough, No. 3:06-CV-334-JDM, 2006 WL 3323222, at*3 (W.D. Ky. Nov. 14, 2006) (refusing to enforce an NCA when the termination without cause "violate [d] its significant representations to [the employee] and its own corporate human resources policy"). Yarbrough 
Finally, the Notes cite a small cluster of cases for the proposition that "a number of courts have expressly distinguished the enforceability of restrictive covenants when the employee was fired for cause from the enforceability of restrictive covenants against an employee discharged without cause." ${ }^{93}$ These opinions add little to the previous authority. ${ }^{94}$

In short, although there is case support for both paragraphs (a) and (b), it is scarcely impressive. And there is no consistent rationale underlying any of the cases in either the "inequitable" or "bad faith" category, the courts refusing to enforce having provided a grab-bag of explanations.

In no particular order, some courts seem to believe that a no-cause discharge somehow bears on the legitimacy of the employer's interests. ${ }^{95}$ Other courts, most explicitly some of the bad faith decisions, seem to ground their result in opposing employer opportunism ${ }^{96}$ and enforcing the employee's probable expectations under the rubric of the implied duty of good faith and fair dealing. ${ }^{97}$ Yet other courts focus on the hardship to the employee separate and apart from any contract terms. ${ }^{98}$

A number of the cases speak in terms of refusing to grant equitable relief, but they fail to explain what makes enforcement of the agreement inequitable. ${ }^{99}$ However, they may be looking to a kind of fault notion: any competitive threat is posed solely by virtue of the employer's actions because, by terminating the employee, it caused the harm it now seeks to be relieved of.

was later affirmed: that factual finding was permissible and Kentucky law permitted an equity court to deny specific enforcement when the employee's discharge had been unfair. Lantech.com, LLC v. Yarbrough, 247 F. App'x 769 (6th Cir. 2007) (citing Crowell v. Woodruff, 245 S.W.2d 447 (Ky. 1951)).

93. RESTATEMENT OF EMP. L. § $8.06 \mathrm{cmt}$. f (AM. L. INST. 2015).

94. One of the cases cited was also listed under the "most courts" rubric, Bishop v. Lakeland Animal Hosp., P.C., 644 N.E.2d 33, 36-37 (Ill. App. Ct. 1994), but two provide some additional support. See Prop. Tax Representatives, Inc. v. Chatam, 891 S.W.2d 153, 157-58 (Mo. Ct. App. 1995) (affirming refusal to enforce restrictive covenant in equity when employee was terminated without cause); Cent. Monitoring Serv., Inc. v. Zakinski, 553 N.W.2d 513, 521 (S.D. 1996) (applying balancing test when employee was terminated without cause).

As for Clinch Valley Physicians, Inc. v. Garcia, 414 S.E.2d 599, 601 (Va. 1992), the Reporters cite it not for the proposition that covenants will not be enforced when the employee is terminated without cause but rather that the courts will construe ambiguous covenants narrowly when possible. In that decision, the Virginia Supreme Court held that nonrenewal of a contract did not trigger a noncompete, which applied only when the termination was for cause. Id. at 601 .

95. See infra note 107.

96. See infra note 132

97. See infra note 139 .

98. See infra note 127

99. See infra note 120 . 
Other decisions talk of no-cause discharges as destroying mutuality of obligation. ${ }^{100}$ Still another explanation looks to something like estoppel: one court viewed a non-cause discharge as reflecting the employer's view that the employee was "worthless," which undercut the claim that he posed a competitive threat. ${ }^{101}$

In short, the "majority rule" courts lack any unified justification for their holdings and, at least at first glance, none of the various possibilities articulated by the various opinions seems persuasive as a matter of traditional contract analysis. ${ }^{102}$ At the same time, the intuition underlying these cases seems quite plausible. Is it possible to articulate a rationale that would justify such a result for future courts ${ }^{103}$ and, perhaps in the process, provide a clearer rule than one that would invalidate a clause when the termination was "inequitable"?

\section{CANVASSING THE RATIONALES}

The Restatement provides that a termination without performancerelated "cause" is sufficient to deprive the employer of the benefit of an otherwise valid restrictive covenant. ${ }^{104}$ Certainly, employer economic concerns are insufficient. ${ }^{105}$ How to justify such a rule? We can put to one side courts that do not worry about doctrine at all but just announced the result, presumably because the answer is self-evident. ${ }^{106}$

Other opinions "fight the hypothetical," that is, they conclude that a nocause discharge undermines the legitimacy of the employer's interests. For example, one decision thought that a termination without cause showed

100. See infra note 113 .

101. See infra note 108 .

102. It may seem odd to worry about the consistency of a rule favoring employees with general contract doctrine when employment law often twists standard doctrine to favor employers. E.g., Hanson v. Cent. Show Printing Co., 130 N.W.2d 654, 655-56 (Iowa 1964) (articulating the traditional rule that, absent an express term of employment, "additional" consideration is necessary to bind the employer to something more than an at-will commitment).

103. Id. at $657-58$.

104. RESTATEMENT OF EMP. L. $\S 8.06 \mathrm{cmt}$. f (AM. L. INST. 2015).

105. See supra note 58.

106. See Orion Broad., Inc. v. Forsythe, 477 F. Supp. 198, 201 (W.D. Ky. 1979) (holding an employee to an NCA that deprives her of her livelihood at the "whim" of her employer is "an example of industrial peonage which has no place in today's society."). 
the employer had no such interest. ${ }^{107}$ Another viewed a non-cause discharge as reflecting the employer's view that the employee was "worthless."108

It is certainly true that a noncompete clause may be unreasonable in the circumstances: if the employee's termination were part of her employer's exiting the business, say, there would be nothing for the ex-employee to compete with. But the employer's basis for protection will rarely vary depending on why the employee left. To see this, imagine the employer's legitimate interest is the employer's investment in facilitating the relationship between customers and the departing employee; to protect this, restraints are typically reasonable if they provide the employer an adequate opportunity to demonstrate that a replacement can provide equally good or better service. ${ }^{109}$ The reason for the departing employee's termination does not really undercut this interest, and the same can be said for protecting trade secrets or other confidential information. ${ }^{110}$

If there's a point to this argument, it must be that the employer had another way to protect itself - retaining the employee - and there is something unfair about choosing to invoke a covenant not to compete against the terminated employee rather than simply keeping her on. Having one's cake and eating it too comes to mind. But, needless to say, there is no general contract law principle that forbids monopolizing cakes, and contracting parties often seek to obtain the sweet without the bitter.

Other courts look more explicitly to doctrine, but the framing in the cases is muddy at best. In Post v. Merrill Lynch, Pierce, Fenner \& Smith, Inc., the New York Court of Appeals invoked not only ERISA's policy against forfeiting pension benefits but also the state's own rules disapproving forfeitures in order to negate an NCA that conditioned pension benefits

107. Wrigg v. Junkermier, Clark, Campanella, Stevens, P.C., 265 P.3d 646, 653 (Mont. 2011) ("[A]n employer normally lacks a legitimate business interest in a covenant when it chooses to end the employment relationship. Maintenance of the employment relationship represents an employer's best method to prevent competition from an employee.").

108. Insulation Corp. of Am. v. Brobston, 667 A.2d 729, 735 (Pa. Super. Ct. 1995) (“[I]t is unreasonable as a matter of law to permit the employer to retain unfettered control over that which it has effectively discarded as worthless to its legitimate business interests."). Interestingly, given the defendant's performance problems, this case could have been viewed as a discharge for cause.

109. See RESTATEMENT OF EMP. L. $§ 8.07$ (AM. L. InSt. 2015).

110. Recall that the Restatement recognizes four legitimate employer interests, the most common of which are protection of trade secrets/confidential information and customer relationships. See id. $\S 8.07(b)(1)$, (2); supra note 47. The employer's interest in protecting both would seem to survive termination for any reason. Arguably, the third, the employer's "investment in the employee's reputation in the market," and perhaps the fourth, "purchase of a business owned by the employee," might be affected by the reason for termination. RestATEMENT OF EMP. L. § 8.07(b)(3), (4) (AM. L. InSt. 2015). 
on not competing. ${ }^{111}$ Whatever the power of any forfeiture analysis, ${ }^{112}$ it will have little application across the mine run of noncompetes which do not involve anything that could conventionally be called a forfeiture.

The same court also invoked the doctrine of "mutuality of obligation" to support its result, writing:

\begin{abstract}
Acknowledging the tension between the freedom of individuals to contract, and the reluctance to see one barter away his freedom, the State enforces limited restraints on an employee's employment mobility where a mutuality of obligation is freely bargained for by the parties. An essential aspect of that relationship, however, is the employer's continued willingness to employ the party covenanting not to compete. Where the employer terminates the employment relationship without cause, however, his action necessarily destroys the mutuality of obligation on which the covenant rests as well as the employer's ability to impose a forfeiture. An employer should not be permitted to use offensively an anticompetition clause coupled with a forfeiture provision to economically cripple a former employee and simultaneously deny other potential employers his services. 113
\end{abstract}

Putting aside the forfeiture aspect, mutuality, if it has a current meaning in contract law, is simply another name for consideration. To the extent the concept requires at least roughly equal commitments on both sides of the transaction, which is how the Post court viewed the concept, it has long been rejected in other areas of contract law. ${ }^{114}$ It is a fairness doctrine,

111. Post v. Merrill Lynch, Pierce, Fenner \& Smith, Inc., 397 N.E.2d 358, 360 (N.Y. 1979).

112. See J.N.A. Realty Corp. v. Cross Bay Chelsea, Inc., 366 N.E.2d 1313, 1322 (N.Y. 1977) (excusing a condition of timely notice for renewal of a lease when tenant would forfeit substantial investment in its business). Thus, a court may excuse the non-occurrence of a condition to a promise - in this case, not competing as a condition of pension benefits where "disproportionate forfeiture" would occur (the loss of pension benefits), unless the condition was a "material part" of the exchange. RestATEMENT (SECOND) OF CONTS. § 229 (AM. L. INST. 1981). Obviously, there is room for debate about the materiality of the noncompetition clause even if there is otherwise a disproportionate forfeiture.

113. Post, 397 N.E.2d at 360-61; see Joseph M. Perillo, Abuse of Rights: A Pervasive Legal Concept, 27 PAC. L. J. 37, 89 n.257 (1995); see also Orion Broad., Inc. v. Forsythe, 477 F. Supp. 198, 200-01 (W.D. Ky. 1979) (holding the covenant to lack mutuality).

114. RESTATEMENT (SECOND) OF CONTS. § 79(c) (AM. L. InST. 1981) ("If the requirement of consideration is met, there is no additional requirement of . . . (c) 'mutuality of obligation."'; see Matthew W. Finkin, Lea VanderVelde, William Corbett \& Stephen F. Befort, Working Group on Chapter 2 of the Proposed Restatement of Employment Law: Employment Contracts: Termination, 13 EMP. RTS. \& EMP. POL'Y J. 93, 117 (2009) ("Mutuality of contract was a principle that provided there was no consideration to support a contract if the economic value given in exchange was much less than that of the promise or the promised performance; this 'mutuality of obligation' was said to be essential to a contract. The drafters of the Restatement (Second) of Contracts abandoned that notion.”). 
and, as one distinguished commentator noted, part of the traditional dogma of contract law is that "[t]here is simply no room for any inquiry into the fairness of the exchange." 115 While there are exceptions to that generalization, most notably unconscionability, ${ }^{116}$ courts that have refused to enforce an NCA have almost never looked explicitly to that doctrine. ${ }^{117}$

However, most noncompetes are litigated in suits seeking injunctive relief, which entails the application of equitable doctrines as to whether the relief should be granted. ${ }^{118}$ Thus, another fairness constraint pops up in the cases speaking in terms of refusing to grant equitable relief, which may explain the use of "inequitable" in the Restatement blackletter. Putting aside the possible suggestion that those courts might reach a different result were the action one for damages, ${ }^{119}$ the question remains what exactly makes specific enforcement inequitable.

Presumably the answer lies in equity maxims like "unclean hands" or "he who seeks equity must do equity." 120 That in turn requires that the plaintiff do something that is in some sense wrongful. ${ }^{121}$ However, the courts looking to equity to refuse to enforce an NCA in this circumstance do not make clear why it is wrongful for an employer to assert its rights under

115. P.S. Atiyah, Contract and Fair Exchange, 35 U. ToronTo L. J. 1, 1 (1985).

116. RESTATEMENT (SECOND) OF CONTS. § 208 (AM. L. INST. 1981); see also U.C.C. $\S \S 2-302,2 \mathrm{~A}-108$ (AM. L. INST. 2020).

117. One of the few cases is Kupscznk v. Blasters, Inc., 647 So. 2d 888, 891 (Fla. Dist. Ct. App. 1994), which recognized the possibility of an unconscionable agreement but seemed to tie it to refusal of a court sitting in equity to deny enforcement.

118. RESTATEMENT OF EMP. L. § 9.04(b), cmt. a (AM. L. INST. 2015).

119. Although often described as limited to equity, many applications of similar reasoning apply at law. See generally, T. Leigh Anenson, Limiting Legal Remedies: An Analysis of Unclean Hands, 99 KY. L.J. 63, 74-75 (2010-11); Zechariah Chafee, Jr., Coming into Equity with Clean Hands: I, 47 MicH. L. REv. 877, 885 (1949); Zechariah Chafee, Jr., Coming into Equity with Clean Hands: II, 47 Mich. L. REv. 1065, 1074 (1949).

120. See T. Leigh Anenson, Announcing the "Clean Hands" Doctrine, 51 U.C. DAVIS L. REV. 1827, 1853 n.147 (2017). The notion is so amorphous that it is hard to call it a doctrine, but it seems to entail at least two concerns: preventing plaintiffs from profiting from their own wrongs and avoiding making the court complicit in those wrongs. Id. at 1840-41 ("The purposes of equity, and its defenses in particular, were to stop strategic behavior and safeguard the court. In this vein, the maxim of 'he [or she] who comes into equity must come with clean hands' developed to 'protect the court against the odium that would follow its interference to enable a party to profit by his own wrongdoing.' It follows that the defense serves two fundamental purposes. It protects judicial integrity and promotes justice.").

121. The wrong must also be somehow connected to the claim that triggered the lawsuit. Anenson, supra note 120, at 1867 ("United States Supreme Court decisions of unclean hands continue to require a relationship between the wrong and the remedy or right. ... But the unclean conduct need not be in the same transaction so long as the events are related. Akin to fraud jurisprudence, it is sufficient if the dirty deed infects the issue before the court.") (citations omitted)). But that would not seem a separate problem in this context since the "wrong" is presumably the termination. 
the contract both to terminate without cause and to be protected from competition thereafter. By hypothesis, the restraint is otherwise reasonable, and the employer is simply asserting its dual contractual rights to discharge at will and to be protected by a reasonable NCA. It may be a hard bargain, but that is traditionally not enough for equity to deny enforcement. ${ }^{122}$

Maybe the unclean hands justification could be predicated on the notion that the harm to the employee is disproportionate to the benefit to the employer. This might explain cases that describe the discharge as indicating that the employer finds the employee "worthless" 123 or labeling the result a kind of "peonage." 124 Such an approach would permit courts to weigh the competing interests but would not seem to support the Restatement's apparent flat rule of nonenforcement.

Another possible justification - that noncompetes have adverse third party effects - seems wrong, at least in the sense that those effects are supposedly weighed in the process of deciding whether a restraint is reasonable to begin with: a "public interest" override on an otherwise reasonable restraint is recognized in Restatement $\S 8.06(i) .{ }^{125}$ It is true that few NCAs are struck down on this ground, but it is also true that the public harm in terms of the loss of competition is no more or less whether a discharge is for convenience or for cause.

Still another justification would look to hardship to the employee, and the traditional multipart test for a reasonable restraint required a finding that it did not impose an undue burden or hardship on the employee. ${ }^{126} \mathrm{~A}$

122. See Columbus Ry. Power \& Light Co. v. City of Columbus, 249 U.S. 399, 414 (1919) ("[T]aking the allegations of the bill to be true, it undoubtedly is, a case of a hard bargain. But equity does not relieve from hard bargains simply because they are such."); Friendly Ice Cream Corp. v. Beckner, 597 S.E.2d 34, 38 (Va. 2004) ("A court of equity will not set aside a contract because it is 'rash, improvident or [a] hard bargain' but equity will act if the circumstances raise the inference that the contract was the result of imposition, deception, or undue influence." (quoting Payne v. Simmons, 350 S.E.2d 637, 640 (Va. 1986))).

123. Insulation Corp. of Am. v. Brobston, 667 A.2d 729, 735 (Pa. Super. Ct. 1995).

124. Orion Broad., Inc. v. Forsythe, 477 F. Supp. 198, 201 (W.D. Ky. 1979).

125. RESTATEMENT OF EMP. L. § $8.06 \mathrm{cmt}$. i (AM. L. INST. 2006).

126. Restatement (Second) of Contracts, section 188 states:

(1) A promise to refrain from competition that imposes a restraint that is ancillary to an otherwise valid transaction or relationship is unreasonably in restraint of trade if

(a) the restraint is greater than is needed to protect the promisee's legitimate interest, or

(b) the promisee's need is outweighed by the hardship to the promisor and the likely injury to the public.

Restatement (SECOND) OF CONTS. § 188 (Am. L. InSt. 1981) (emphasis added). 
non-cause discharge imposes a great hardship on the employee who loses both his current paycheck and the prospect of substitute employment - at least within the restricted area. ${ }^{127}$ However, the Restatement of Employment Law correctly states that "undue burden" is almost never the basis for modern courts refusing to enforce an otherwise-reasonable covenant. ${ }^{128}$ Nevertheless, many jurisdictions still pay lip service to the principle that a valid covenant cannot impose an undue hardship on the former employee, ${ }^{129}$ so there is at least an extant rubric under which to slot concern for the employee terminated without cause.

The problem, of course, is that the fix the employee is in is the same whether she voluntarily quit, was terminated for cause, or was terminated for the employer's convenience. If hardship plays a bigger role here, it is not because of the employee's situation, but because the employer exercised its contractual rights to her disadvantage. This is not to say that there is no difference among the possible reasons for job loss, only that "hardship" does not capture that difference.

Some courts have suggested that enforcement in such cases may violate the duty of good faith and fair dealing, ${ }^{130}$ which is implied in every contract ${ }^{131}$ and sometimes offers a remedy for employer opportunism. ${ }^{132}$ For example, one opinion suggested that a discharge in such a situation might indicate that the employer was simply seeking to insulate itself from competition, not to protect its legitimate interests. ${ }^{133}$ Noting that the governing contract was terminable at will, it saw the situation as

present[ing] the potential for an unreasonable restraint of trade. For example, if an employer hired an employee at will, obtained a covenant not to compete, and

127. Macintosh v. Brunswick Corp., 215 A.2d 222, 225-26 (Md. 1965) (holding that restrictive covenant imposed "undue hardship" on the employee in part because employee was fired "through no fault of his own").

128. RESTATEMENT OF EMP. L. $\S 8.06 \mathrm{cmt}$. b (AM. L. INST. 2006) ("Courts often claim to evaluate whether a restrictive covenant creates an undue burden on the employee who agreed to it. However, courts seldom, if ever, invalidate covenants solely on this ground .... At most, it seems that the undue-burden requirement is a tack-on rationale courts use only when a restrictive covenant is otherwise invalid.").

129. A number of jurisdictions have some variation of section 188 of the Restatement (Second) of Contracts. See supra note 127; Ellis v. James V. Hurson Assocs., Inc., 565 A.2d 615, 618 (D.C. 1989).

130. E.g., Bishop v. Lakeland Animal Hosp., PC, 644 N.E.2d 33, 36 (Ill. App. Ct. 1994) ("[T] enforcement of a noncompetition clause when the employee is dismissed without cause.").

131. RESTATEMENT (SECOND) OF CONTS. § 205 (AM. L. INST. 1981).

132. See Bailey v. King, 398 S.W.2d 906, 908 (Ark. 1966) ("[I]f an employer obtained an agreement of this nature from an employee, and then, without reasonable cause, fired him, the agreement would not be binding. In other words, an employer cannot use this type of contract as a subterfuge to rid himself of a possible future competitor.").

133. Hopper v. All Pet Animal Clinic, Inc., 861 P.2d 531, 541 (Wyo. 1993). 
then terminated the employee, without cause, to arbitrarily restrict competition, we believe such conduct would constitute bad faith. Simple justice requires that a termination by the employer of an at will employee be in good faith if a covenant not to compete is to be enforced. 134

However, the court found no bad faith in the case before it, ${ }^{135}$ and that would seem to be true in almost any situation where the employment continued for a meaningful length of time before the termination. In other words, the argument makes sense when the NCA is signed on Monday and the employee laid off on Tuesday, ${ }^{136}$ but it has less obvious application when the no-cause termination occurs months or years later. A motive to enter into the contract merely to take the employee off the competitive boards seems vanishing unlikely in such situations. ${ }^{137}$

But two scholars have advanced important variations on the theme, ones that do not require finding an employer plot at the outset. Rather, they argue that in such situations the employer is violating an implicit bargain-the employee gets her job in return for satisfactory work so long as she chooses to continue her employment. ${ }^{138}$ The earliest law review article to briefly notice these cases was written by Professor Joseph M. Perillo who fitted them within a paradigm he described as "abuse of rights":

The shared purpose of an employment agreement containing a covenant not to compete is to protect the employer from conduct that is in the penumbra of unfair competition while assuring the employee a means of practicing the trade or profession for which the employee is trained. The employee's purpose in agreeing to the covenant is to practice this trade or profession with the employer who has now destroyed the assurance of a job while seeking to prevent the employee from working at such a job elsewhere. Such enforcement would be a grave abuse of rights. 139

\section{Id. \\ 135. See id. at 548 . \\ 136. See supra note 87.}

137. This ignores the possible strategic uses of NCAs to tie up potential competitors as a hedge against the failure to achieve more ambitious goals.

138. See, e.g., Perillo, supra note 87 at 89.

139. Id. See also 15 CORBIn On CONTRACTS: CONTRACTS CONTRARY to PubliC POLICY $\S 80.15$ (2003) (while "[c]lassical contract law would suggest that the lack of cause for the termination should be irrelevant to the enforceability of restrictive covenants[,] many courts do not enforce covenants if the termination is without cause" (citation omitted)). That discussion draws heavily on Perillo.

The classic article on such restraints mentions the circumstances of termination only in a brief paragraph that focuses mostly on withholding of equitable relief. Harlan M. Blake, Employee Agreements Not to Compete, 73 HARV. L. REV. 625, 685 (1960). 


\section{Professor Rachel Arnow-Richman takes a similar tack:}

[T]he judicial trend toward disallowing enforcement in the involuntary termination context is consistent with the parties' understanding of their implicit agreement and the limits of the employer's interest in its workers. The act of terminating the employee [without cause] belies the existence of any continued interest in the employee's skills, commitment, or services that could justify a restraint, regardless of the employer's expectations at the outset of the relationship. Indeed, in situations in which the employee is terminated the implicit agreement of the new workplace specifically contemplates that the employee will be able to resell his human capital to competitors. 140

In short, this rationale depends on a tacit understanding that the employee will be allowed to continue to earn her living in her chosen field - by working either for the current employer or for a competitor.

I have no doubt that both scholars are correct in terms of how employees would describe their expectations if asked, but subjective expectations have had little effect on the law's treatment of contractual commitments, hence the dominance of the at-will rule to begin with. ${ }^{141}$ In any event, the problem with this approach is the doctrinal qualification that the implied covenant of good faith and fair dealing does not override express terms of a contract. ${ }^{142}$ An employment agreement that both permits termination at

140. Rachel S. Arnow-Richman, Bargaining for Loyalty in the Information Age: A Reconsideration of the Role of Substantive Fairness in Enforcing Employee Noncompetes, 80 OR. L. REV. 1163, 1217 n.186 (2001) (citation omitted). But see Andrew J. Gallo, Comment, A Uniform Rule for Enforcement of Non-Competition Contracts Considered in Relation to “Termination" Cases, 1 U. PA. J. LAB. \& EMP. L. 719, 719 (1997-98) (arguing against any special rule for termination cases).

141. See Pauline T. Kim, Bargaining with Imperfect Information: A Study of Worker Perceptions of Legal Protection in an At-Will World, 83 CoRNELL L. REV. 105, 133-36 (1997) (finding that a majority of employee respondents erroneously believed that the law protected them from certain types of arbitrary discharge).

142. See Beidel v. Sideline Software, Inc., 842 N.W.2d 240, 251 (Wis. 2013) ("A party may not, however, employ the good faith and fair dealing covenant to undo express terms of an agreement."). That is the basis for the almost unanimous holdings of courts that the implied duty cannot override the employer's right to terminate in the at-will context. See Guz v. Bechtel Nat'1, Inc., 8 P.3d 1089, 1110 (Cal. 2000) ("Precisely because employment at will allows the employer freedom to terminate the relationship as it chooses, the employer does not frustrate the employee's contractual rights merely by doing so.").

The Restatement of Employment Law recognizes the implied covenant but largely limits it to dealing with opportunistic conduct not explicitly authorized by the contract, "which includes a party's obligation not to hinder the other party's performance under, or deprive the other of the benefit of," the contract. RESTATEMENT OF EMP. L. § 2.07(a) (AM. L. INST. 2015). That duty must be read "in a manner consistent with the essential nature of an atwill relationship." Id. $\S 2.07$ (b). The Restatement conforms with case law establishing that the implied covenant "includes the duty not to terminate ... the employment relationship for the purpose of ... preventing the vesting or accrual of an employee right or benefit ...." Id. § 2.07(c)(1); see generally Lea VanderVelde, Where Is the Concept of Good Faith in the Restatement of Employment?, 21 EMP. RTS. \& EMP. POL'Y J. 335 (2017). 
will and contains a noncompetition clause arguably does precisely that. And it certainly does so when the clause in question expressly reaches involuntary not-for-cause discharges. ${ }^{143}$

\section{A FRESH LOOK}

The starting point for any discussion of the principles governing noncompetition agreements is the recognition that, contrary to contract law's general preference for private ordering, NCAs are subject to significant legal constraints. The Restatement accurately reflects the common law's departure from normal freedom of contract analysis both by limiting the employer's interests to those deemed "legitimate" and by requiring tailoring of the restraint to those interests. ${ }^{144}$ Although different jurisdictions adopt variations on the theme, ${ }^{145}$ there is universal recognition that employers and employees are not given free rein in postemployment restraints. ${ }^{146}$

The current justification for such an approach is the third-party effects of NCAs. That is, the law intervenes to ensure that the public is protected by preserving competitive markets: cases are legion reciting that employers have no legitimate interest in suppressing competition as such. ${ }^{147}$ Oddly,

143. There might be room for a court to find ambiguity in some NCAs. Thus, a contract that provided only for operation of the noncompete after termination might be read as unclear as to what kind of termination. For example, an actual NCA used by a financial services firm provides:

I agree that during the course of my employment and for a period of 6 months immediately following the termination of my relationship with the Company, whether I resign voluntarily or am terminated by the Company involuntarily . . .

On file with the author. Involuntarily might be read to mean "for cause," or at least be ambiguous as to that possibility. On the other hand, a similar agreement of another financial services firm provides:

[You] agree that while you are employed with [firm], and for the length of time

set forth in each subparagraph below following the termination of your employment for any reason whatsoever...

On file with the author (emphasis added). It is hard to see much room for the implied covenant to operate in this NCA.

144. ReSTATEMENT OF EMP. L. $§ 8.07$ (AM. L. InSt. 2015).

145. Stuart S. Menela, Post-Employment Agreements Not to Compete (US), Assoc. OF CORP. COUNS. (Feb. 4, 2015), https://www.acc.com/resource-library/post-employmentagreements-not-compete-us\# [https://perma.cc/33K9-LUL6].

146. See generally id.

147. E.g., Weber v. Tillman, 913 P.2d 84, 89 (Kan. 1996) (" $[\mathrm{I}] \mathrm{t}$ is well settled that only a legitimate business interest may be protected by a noncompetition covenant. If the sole purpose is to avoid ordinary competition, it is unreasonable and unenforceable."). See also RESTATEMENT OF EMP. L. $§ 8.07$ cmt. f (AM. L. InSt. 2015) (“[A]n employer's 
however, avoidance of adverse third party effects, although it underlies the law's entire approach to noncompetition agreements, appears in formal doctrine only as one factor in the reasonableness analysis. ${ }^{148}$ Further, it rarely has independent significance if the other requirements are met. ${ }^{149}$ Indeed, the Restatement downplays this factor even more by providing for nonenforcement only where there is "a great public need for the special skills and services of the former employee [that] outweighs any legitimate interest of the employer in enforcing the covenant." ${ }^{150}$ In other words, for the Restatement, the public's interest in competition is essentially baked into deciding whether the restraint is reasonably tailored, with public need for services being a rare exception to the law's approval of an appropriately circumscribed restraint. Although common law courts do not typically frame the exception so narrowly, they rarely invalidate an otherwise reasonable restraint on this ground, and, even then, almost always in the context of medical services. ${ }^{151}$

And, while we need not revisit what courts should do when the restraint as written is excessive, ${ }^{152}$ the many cases where the courts strike down an

understandable wish to prevent competition by former employees is not, by itself, a protectable interest under this Section.").

148. E.g., Star Direct Inc. v. Dal Pra, 767 N.W.2d 898, 905 (Wis. 2009) (“A restrictive covenant must: (1) be necessary for the protection of the employer, that is, the employer must have a protectable interest justifying the restriction imposed on the activity of the employee; (2) provide a reasonable time limit; (3) provide a reasonable territorial limit; (4) not be harsh or oppressive as to the employee; and (5) not be contrary to public policy." (citing Lakeside Oil Co. v. Slutsky, 98 N.W.2d 415 (Wis. 1959)); Boice-Willis Clinic, P.A. v. Seaman, No. COA05-298, 2005 N.C. App. LEXIS 2688, at *6 (Ct. App. Dec. $20,2005)$ (covenant cannot be "so broad as to be oppressive to the covenantor or the public," which may require an inquiry as to "a substantial question of potential harm to the public health."); Weber, 913 P.2d at 89 ("A noncompetition covenant ancillary to an employment contract is valid and enforceable if the restraint is reasonable under the circumstances and not adverse to the public welfare.").

149. Lawrence Peikes \& Michael J. Kasdan, Limitations and Best Practices for Using Non-Competition Agreements to Protect Company Trade Secrets, NAT'L L. REV. (Jan. 8, 2020), https://www.natlawreview.com/article/limitations-and-best-practices-usingnon-competition-agreements-to-protect-company [https://perma.cc/8EVZ-8LS6].

150. RESTATEMENT OF EMP. L. § 8.06(d) (AM. L. INST. 2015) (emphasis added).

151. See, e.g., Aesthetic Facial \& Ocular Plastic Surgery Ctr., P.A. v. Zaldivar, 826 S.E.2d 723, 730 (N.C. Ct. App. 2019) (invalidating as against public policy a covenant restricting surgeon's "ability to practice in the most populated areas of North Carolina when there are very few oculofacial plastic surgeons, and even fewer who perform some of the specialized procedures he is trained to provide"); Cmty. Hosp. Grp., Inc. v. More, 869 A.2d 884, 899 (N.J. 2005) ("The evidence was overwhelming that prohibiting Dr. More from attending to neurological patients in Somerset's emergency room would be injurious to the public interest.").

152. See generally Charles A. Sullivan, The Puzzling Persistence of Unenforceable Contract Terms, 70 OHIo St. L.J. 1127 (2009). See, e.g., Team Env't Servs. v. Addison, 2 F.3d 124, 127 (5th Cir. 1993) (suggesting that modifying unreasonably broad covenants 
NCA entirely or at least narrow its length, space, or sweep in order to render the restraint reasonable ${ }^{153}$ testify to the tendency of employers to overreach in efforts to foreclose competition and the corresponding willingness of courts to rein in those efforts.

This judicial reaction can be explained as an effort to minimize third party effects, but the overall doctrinal structure not only furthers the public interest in competition but also necessarily protects employees from employers overreaching. Might this in turn suggest a possible second purpose to the law of postemployment restraints: protecting the weaker party in such transactions? There are hints of such a view scattered in the Restatement. For example, $\S 8.06$ comment a notes a negative aspect of restrictive covenants as their "inhibit[ing] the freedom of employees to leave their employers and move to other employment where the employees may be more productive" as a separate concern from the public interest in competition. ${ }^{154}$ And comment $\mathrm{f}$ to $\S 8.07$, while recognizing that an employer "may have many economic reasons to attempt to restrict what its employees can do after termination of their employment," concludes that only the approved ones are "sufficiently weighty to justify the social and individual costs inherent in restrictions on competition." 155

Admittedly, there is more than a little tension between any concern for employees separate and apart from third party harms and the Restatement's explicit rejection of protection of employees from undue hardship. But arguably the Restatement's stance can be reconciled: it rejects hardship as a constraint on reasonable restraints only when the employee is free to earn a living but chooses to resign or gives cause to be discharged. Hardship enters the picture when that basic assumption disappears.

incentivizes overbreadth); Ferrofluidics Corp. v. Advanced Vacuum Components, Inc., 968 F.2d 1463, 1469 (1st Cir. 1992) (detailing various judicial approaches to the question of overbroad clauses). The Employment Restatement permits judicial modification unless barred by the agreement or "the employer lacked a reasonable and good-faith basis for believing the covenant was enforceable.” RESTATEMENT OF EMP. L. § 8.08 (AM. L. INST. 2015). It continues: "Lack of a reasonable and good-faith basis for believing a covenant was enforceable may be manifested by its gross overbreadth alone, or by overbreadth coupled with other evidence that the employer sought to do more than protect its legitimate interests." Id.

153. See Restatement Of EMP. L. $\S 8.08 \mathrm{cmt}$. a (AM. L. InST. 2015).

154. Id. $\S 8.06 \mathrm{cmt}$. a.

155. Id. $\S 8.07 \mathrm{cmt}$. f (emphasis added). It goes on to say that recouping training costs might support an obligation to repay but not a noncompetition clause. Id. See generally Jonathan F. Harris, Unconscionability in Contracting for Worker Training, 72 ALA. L. ReV. 724 (2021). 
This reconciliation may be too-clever-by-half as an explanation of the actual Restatement. But, Restatement aside, it does suggest an alternative basis for intervention in some circumstances: protection of the right of the individual to practice a chosen trade or profession. NCAs, of course, necessarily limit that right to a considerable extent, but they do not negate it so long as the employee may continue working for her employer. And, to the extent that the employee resigns voluntarily or loses her position for performancerelated cause, she can be said to have elected the resultant sidelining.

The right may have constitutional roots in terms of the Thirteenth Amendment and "free labor" scholarship, ${ }^{156}$ but the common law need not look to such sources to recognize that agreements that wholly preclude an individual from practicing her trade or profession, even for a limited time, raise serious fairness concerns. These concerns are reflected, if not articulated clearly, in the various decisions we have surveyed holding or suggesting that an employer who fires a worker without cause cannot enforce a noncompete. So long as the worker remains employed, she can continue to work and forfeits that right only by resigning or giving her employer good cause to discharge her. In contrast, enforcing a noncompete against a worker who is terminated without good cause deprives her of the right to work in her chosen trade or profession for the duration of the restraint.

Indeed, to the extent that legal restraints on NCAs are effective, they necessarily benefit both the public and the employee. Instead of viewing this as a kind of artifact of limiting noncompetes to those reasonably furthering legitimate aims in terms of the public interest, it might be viewed as a second justification. Under that approach, $\S 8.06$ 's invalidation of otherwise-reasonable restraints when they are inequitable merely extends the general principle rather than creating an exception to it. The cases approving such a rule can be viewed not as incoherent but as inarticulate. Nor does contract law's normal disdain for fairness overrides matter since we are in an area in which fairness is a legitimate part of the judicial inquiry and judicial intuitions can be expressed more directly.

In short, enforcement is denied because the benefit to the employer is likely to be disproportionate to the harm to the employee; the employer

156. See Ayesha Bell Hardaway, The Paradox of the Right to Contract: Noncompete Agreements as Thirteenth Amendment Violations, 39 SeAtTLE U. L. ReV. 957, 978 (2016) (arguing that for low-wage workers, NCAs violate the Thirteenth Amendment); Lea S. VanderVelde, The Labor Vision of the Thirteenth Amendment, 138 U. PA. L. REV. 437, 439 (1989). But see Jamal Greene, Thirteenth Amendment Optimism, 112 Colum. L. REV. 1733, 1737 (2012) (expressing doubts about the likelihood of judicial acceptance of expansive readings of the Thirteenth Amendment); Pamela Brandwein, The "Labor Vision" of the Thirteenth Amendment, Revisited, 15 GEO. J.L. \& PUB. POL'Y 13, 14 (2017) (challenging the historical claim that the Thirteenth Amendment was "a charter for labor freedom and class leveling”). 
could have avoided any harm by retaining the employee; whatever the contract says, the reasonable employee would not anticipate a no-cause discharge depriving her of her livelihood entirely for the duration of the restraint; and the court, especially one sitting in equity, should not be complicit in such unfairness. In other words, looking to the cases, all of the above.

There are at least two responses to this. One simply challenges the fairness claim. It is true that NCAs restrict individual freedom, but, given the legal constraints circumscribing their use, the harm is arguably minimal and always temporary. Rarely will a valid NCA actually prevent an employee from practicing her trade, and then for only a limited period. More likely, a valid NCA will only prevent (and often only limit) her from doing so in a fairly narrow geographic area. Given the multifaceted ways in which employees are free to agree on limitations of their conduct, an otherwise-reasonable NCA is arguably small potatoes.

Second is the question why the law should put a fairness thumb on the scale for employees rather than leave the issue to the market. If the Route 128 debate is resolved in favor of the California model, the issue disappears, but if supporters of the efficiency-enhancing effects of noncompetes win the day, fairness concerns arguably have no place.

Even then, however, more nuanced treatment of NCAs might be appropriate. It has long been recognized that one effect of postemployment restraints is to impede employee mobility, that is, they put a kind of tax on employee's leaving for greener pastures, ${ }^{157}$ and some even argue that that is a major, if rarely acknowledged, purpose of such clauses. ${ }^{158}$ Such a tax undercuts the threat of the employee's departing and thus her bargaining position with her current employer and therefore should result in lower compensation than would obtain absent the restraint. Defenders of the current rule suggest that, at least in competitive markers, compensation will be set higher to begin with to offset that disadvantage. ${ }^{159}$ In other words, they argue that the compensation affects may be more or less a wash.

Whatever economists might say, employers apparently think that they save labor costs by deploying noncompetes. That can be seen, absent recent legislative prohibitions, ${ }^{160}$ in their increasing use in the low end of the

157. Blake, supra note 139, at 648 (courts recognize that "an employee covenant has an inevitable tendency to reduce an employee's mobility and bargaining power during his employment.").

158. See Barnett \& Sichelman, supra note 12, at 1034.

159. Id. at 1037.

160. Id. at 1032 . 
labor market where no plausible competitive harm exists. ${ }^{161}$ It also is reflected in the use of nonpoaching agreements where state law forecloses enforceable NCAs. Given the risks of antitrust liability, such employers must anticipate a payoff. ${ }^{162}$

The limited empirical work thus far suggests some truth to both positions; one study finds a meaningful positive association with higher wages for workers who are presented with noncompetes as part of the job offer but a large negative effect for those who are required to sign NCAs after employment commences. ${ }^{163}$ It might be that fairness concerns, therefore, play out in greater regulation rather than a flat-out ban on noncompetes. Indeed, some of the current reforms seek to ensure informed consent by employees, ${ }^{164}$ or "additional compensation" for NCAs executed mid-term. ${ }^{165}$

161. See Lobel, supra note 2, at 672-73 (reporting class actions challenging franchise nohire agreements by "many fast food franchises including Carl Karcher Enterprises (Carl's Jr.), McDonald's, Pizza Hut, Jimmy John's, Arby's, Cinnabon, Little Caesars, Burger King, and Dunkin Donuts").

162. Litigation involving no-poaching agreements by some of the biggest technology firms in Silicon Valley ended with a Department of Justice consent decree with the defendants and the settlement of a class action subsequently brought on behalf of the engineers whose compensation was allegedly suppressed by the agreement. See Lobel, supra note 2, at 668-69; see also U.S. DeP'T of Just. Antitrust Div., Fed. Trade Comm’n, Antitrust Guidance for Human Resource Professionals (2016).

163. Starr, Prescott \& Bishara, supra note 41, at 12 (finding that those "who learn of their noncompete before accepting their job" have higher earnings and greater job satisfaction than employees without noncompetes). "In contrast, those presented with a noncompete after accepting their job offer (excluding those furnished with a noncompete following a promotion or a change in responsibilities) appear to receive no observable boost in wages or training, are 13.4 percentage points less likely to have had information shared with them (a $24 \%$ reduction), and are 8.5 percentage points less likely to be satisfied in their jobs (a $12.5 \%$ reduction)"). Id.; see also Natarajan Balasubramanian et al., Locked In? The Enforceability of Covenants Not to Compete and the Careers of High-Tech Workers 8 (Ross Sch. of Bus., Working Paper No. 1339, 2017) ("Compared with their peers in lowenforceability states, we find no evidence that the reduced mobility of tech workers in high-enforceability states is offset by higher wage levels. In contrast, consistent with reduced bargaining power in high $\mathrm{CNC}$ regimes ... we find that tech workers, conditional on their initial wage, earn lower wages (between $-0.5 \%$ and $-0.7 \%$ for a one-standarddeviation increase in $\mathrm{CNC}$ enforceability) throughout their job spell in higher enforceability states. Our results show that at every phase of job tenure, conditional on their initial wage at a firm, tech workers in high-enforceability states earn less than their counterparts in lower enforceability states. In fact, we find that starting a job in a high-enforceability state results in persistently lower wages over the next eight years of the worker's career. Together, our results strongly suggest that CNC enforceability is associated with a 'job lock.'” (citations omitted)).

164. See supra note 27.

165. See supra note 27. 


\section{A NO-PROBLEM PROBLEM?}

Having spilled a fair amount of ink on the question of enforcement against laid-off workers, it is fair to ask whether this might not be a noproblem problem. That is, one possibility for the relative paucity of case law on the question is simply that employers rarely seek to enforce NCAs when they terminate their workers without cause. While there is a steady trickle of decisions raising the issue, ${ }^{166}$ it is scarcely a stream. Of course, that may be in part a function of the relatively constrained use of noncompetes in past decades and provides no guarantee that the more common deployment of them in the modern workplace will not generate more efforts. Further, enforcement is more likely as competition becomes more severe and it is possible that a post-COVID world will see even more aggressive efforts to curb threats perceived to be posed by former employees.

But it is also true that, as I have argued at length elsewhere, ${ }^{167}$ that the mere existence of an NCA may discourage former employees - and their potential new employers - from entering into competitive businesses. ${ }^{168}$ Adoption by a few key courts of the Restatement rule would, at least for well-advised employees, alleviate this problem somewhat. Alternatively, adding such a principle to various legislative reforms should be considered. But, ultimately, the elimination of the in terrorem effects of unenforceable NCAs will require some sanction beyond merely voiding the provision. Absent that, "how can it hurt?" is likely to be the default principle for employers and their attorneys.

\section{UNINTENDED CONSEQUENCES}

Employers are not likely to remain quiescent should the Restatement's view gain traction and result in NCAs being enforceable only when the employee voluntarily resigns or is fired for material breach. While such a rule may well cause employers to rethink some prospective terminations,

166. Sullivan, supra note 152 , at 1129 n.9, 130 n.12 (explaining that employers may have employees sign unenforceable NCAs, counting on the in terrorem value of the contract regardless of enforceability).

167. Id. at 1129. Recent research has confirmed the widespread use of NCAs even in states where they are clearly unenforceable. J.J. Prescott, Norman D. Bishara \& Evan P. Starr, Understanding Noncompetition Agreements: The 2014 Noncompete Survey Project, 2016 Мich. ST. L. REV. 369, 461 (2016).

168. Sullivan, supra note 152 , at 1129. 
the more common reaction is likely to be resistance to its application and efforts to exploit its weaknesses.

One is the notion of constructive discharge, which $\S 8.06$ clearly intends to apply in this context. ${ }^{169}$ In other settings, it means something like the employer having "created an intolerable situation in which a reasonable employee would feel compelled to quit." ${ }^{\prime 70}$ But the context in which the concept arises is generally employer action in retaliation for exercising protected rights, whether under the public policy tort ${ }^{171}$ or other statutes. ${ }^{172}$ It is not clear whether an employer who substantially changes an employee's working conditions, which is normally within its rights for at-will employees, will have constructively discharged a worker for purposes of $\S 8.06(\mathrm{a})$. Perhaps the drafters had in mind actions intended to lead to a resignation, ${ }^{173}$ not the kind of changes that might result from changing economic and business conditions, but that needs to be resolved and resolution of this question may be critical to the success of the Restatement formulation.

In addition to resisting the adoption of the rule in the courts, employers are likely to alter their practices and their contracts. Practice-wise, one would anticipate an increase in discharges labelled as performance-based when preserving a noncompete is important. Whether the action is justified or the so-called cause manufactured, the effect is likely to be fewer "layoffs" and more performance-related discharges with associated economic - possible loss of unemployment insurance and severance compensation - emotional, and reputational harm.

As for contracts, since cause is defined by the Restatement to mean material breach by the employee or something quite like it, ${ }^{174}$ employer-side attorneys are likely to draft contracts that are more specific in terms of duties and conduct to assure that, should it be necessary, a termination can be labelled for cause.

Otherwise, employers would find themselves in ambiguous situations. For example, in Hopper v. All Pet Animal Clinic, ${ }^{175}$ the court found that the termination of an at-will employee did not invalidate the noncompetition

169. See supra note 59.

170. ReSTATEMENT OF EMP. L. $§ 5.01$ cmt. c, illus. 1 (AM. L. InSt. 2015).

171. Id.

172. See, e.g., Pa. State Police v. Suders, 542 U.S. 129, 129-30 (2004) (discussing

Title VII of the Civil Rights Act of 1964).

173. Under Title VII, some courts required both intolerable working conditions and proof that such conditions were imposed in order to force plaintiff to leave in order to find a constructive discharge. E.g., Gosbin v. Jefferson Cty. Comm'rs, 725 F. App'x 377 (6th Cir. 2018) (citing cases). If this theory were ever tenable, it has likely been laid to rest by Green v. Brennan, 136 S. Ct. 1769 (2016), for Title VII but might be revived in determining whether an NCA should be enforced against a resigning employee.

174. See ReSTATEMENT OF EMP. L. § 2.04 (AM. L. InST. 2015).

175. All Pet Animal Clinic, Inc. v. Hopper, 861 P.2d 531, 541 (Wyo. 1993). 
clause because it was in good faith. But the result might well be different under the Restatement rule. Dr. Hopper was fired for exploring the purchase of a competing practice, ${ }^{176}$ which may or may not have constituted an anticipatory repudiation ${ }^{177}$ and therefore a material breach; thus, absent language explicitly prohibiting such conduct, the Restatement rule might very well bar enforcement.

Indeed, there is a potential moral hazard problem here: an employee wishing to leave might slack off in her performance in order to trigger a discharge. How likely it is that employees might produce subpar results without being in material breach is another question, but, should this rule be widely accepted, employers may start drafting even at-will contracts with requirements that would constitute material breach should the employee not comply. ${ }^{178}$ While the employer will not need cause to discharge, it will need cause to enforce any NCA, and it is likely that the courts will defer to the employer's specification of what constitutes acceptable performance. One downside is that there is likely to emerge a third variety of "for cause" provisions rather than the Restatement's current two. ${ }^{179}$

Whether these risks are sufficient reasons to reject the Restatement's rule is another question entirely.

176. Id. at 542 ("Trial testimony presented evidence of increasing tension prior to termination in the professional relationship between Dr. Johnson and Dr. Hopper. This tension, however, did not appear to result in the termination. The notice of termination was given after Dr. Hopper was confronted about her negotiations to purchase a competitive practice and after Dr. Hopper had termed the employment contract worthless.").

177. See Restatement (SECOND) OF CONTS. § $250 \mathrm{cmt}$. b (AM. L. INST. 1981) (requiring action to be "definite" and "unequivocal" to constitute a repudiation). In any event, defendant's conduct almost certainly gave the employer "reasonable grounds for insecurity" that would have enabled it to demand adequate assurances of performance, and the failure of the employee to provide such an assurance would constitute an anticipatory repudiation). Id. § 251 .

178. This possibility has already been raised in Massachusetts which, as we have seen, by statute bars NCA enforcement for those discharged without cause. See Feblowitz, supra note 27, at 2286 ("An otherwise valid noncompete is unenforceable against an employee who is terminated without cause, so employers may seek to expand the definition of cause in their employment contracts. It remains to be seen whether the contracting parties or the courts will be responsible for determining what does and does not constitute cause for termination.").

179. See supra note 55. 
Whatever the general reception of the Restatement of Employment Law, its drafters deserve credit for having surfaced an important but littlenoticed aspect of the enforcement of noncompetition agreements. They also deserve credit for formulating a rule that puts fairness to employees front-and-center by rejecting enforceability when an employee is terminated without performance-related cause. Although the issue has been relatively rarely litigated in the past, wholesale COVID-related layoffs may propel it to new prominence, and the American Law Institute has come out on the right side. 